\title{
Lise Öğrencilerinin İnternet Algılarının Kelime İlişkilendirme Testi Kullanılarak Íncelenmesi*
}

\author{
Sinem MIHÇI ${ }^{1}$ (D) Ahmet Oğuz AKTÜRK ${ }^{2}$ (iD
}

${ }^{1}$ Giresun Üniversitesi, Giresun, Türkiye, sinem.mihci@giresun.edu.tr

${ }^{2}$ Necmettin Erbakan Üniversitesi, Konya,Türkiye, aoakturk@erbakan.edu.tr

* Bu çalışma birinci yazarın Yüksek Lisans tezinin bir bölümünden oluşmaktadır.

\begin{tabular}{l} 
Makale Bilgileri \\
\hline \hline Makale Geçmişi \\
Geliş: 31.12 .2020 \\
Kabul: 30.12 .2021 \\
Yayın: 31.12 .2021 \\
Anahtar Kelimeler: \\
Bilişim Teknolojileri, \\
Kelime İlişkilendirme \\
Testi, \\
İnternet Algıları
\end{tabular}

ÖZ

Bu çalışmanın amacı, lise öğrencilerinin internet algılarını tespit etmek ve internet ile ilgili zihinlerindeki kavramlar arasındaki ilişkilerin nasıl oluştuğunu belirlemektir. Nitel araştırma desenlerinden olgu bilim (fenomenoloji) deseni kapsamında yürütülen bu araştırmanın verilerinin toplanmasında kelime ilişkilendirme testi kullanılmıştır. Araştırmanın katılımcılarını Konya ili merkezinde bulunan bir Anadolu Ticaret Meslek Lisesi'nin farklı bölümlerinde öğrenim gören 251'i kadın ve 224'ü de erkek olmak üzer toplam 475 öğrenci oluşturmaktadır. Öğrencilere internet ile ilgili 12 anahtar kavramdan oluşan kelime ilişkilendirme testi ön test ve son test olarak uygulanmıştır. Kelime ilişkilendirme testinin ön test olarak uygulanması aşamasında öğrencilerin anahtar kavramlarla ilgili ilk akıllarına gelen cevap kelimelerini yazmaları istenmiştir. Kelime ilişkilendirme ön testi aşamasından sonra öğrencilere "İnternet Kavramları Semineri” eğitimi verilmiştir. Bu seminer eğitiminden hemen sonra aynı kelime ilişkilendirme testi öğrencilere son test olarak uygulanmıştır. Kelime ilişkilendirme testinin öğrencilere ön ve son test olarak uygulanması sonucunda elde edilen verilerden bir frekans tablosu oluşturulmuştur. Bu frekans tablosu yardımıyla öğrencilerin internet ile ilgili bilişsel yapılarını ortaya koyan ön ve son kavram ağı haritaları çizilmiştir. Ön ve son kavram ağlarında ortaya çıkan ilişsilere göre veriler analiz edilerek yorumlanmıştır. Araştırma sonucunda öğrencilerin internet algılarında yoğun olarak "Facebook, Twitter, Google ve Yandex" kelimelerini kullandıkları görülmüştür. Öğrenciler, anahtar kavram olarak Sosyal Ağlar ve Arama Motoru anahtar kavramları hakkında yoğun olarak cevap vermişlerdir. Elde edilen sonuçlar, öğrencilerin bilişsel yapılarında internet ile ilgili kavramlar hakkında bilgi yanlışlarının ve eksikliklerinin olduğunu göstermektedir.

\section{The Examination of Internet Perceptions of High School Students through the Word Association Test}

\begin{tabular}{|c|c|}
\hline Article Info & ABSTRACT \\
\hline $\begin{array}{l}\text { Article History } \\
\text { Received: } 31.12 .2020 \\
\text { Accepted: } 30.12 .2021 \\
\text { Published: } 31.12 .2021 \\
\text { Keywords: } \\
\text { Information } \\
\text { Technologies, } \\
\text { Word Association } \\
\text { Test, } \\
\text { Internet Perceptions }\end{array}$ & $\begin{array}{l}\text { The purpose of this study is to determine high school students' perceptions regarding the internet and identify } \\
\text { how the relationships between concepts about the internet are formed in their minds. The word association } \\
\text { test was used to collect the data of the study, which was conducted within the framework of phenomenology } \\
\text { design, which is one of the qualitative research designs. The participants of the study consist of a total of } \\
475 \text { high school students, } 251 \text { female and } 224 \text { male, attending different departments of Anatolian Vocational } \\
\text { High School of Commerce in Konya metropolitan city. The word association test, which is composed of } 12 \\
\text { key concepts about the internet, was administered to the students as pre-test and post-test. At the stage of the } \\
\text { administration of the word association test as a pre-test, the students were asked to write down the words } \\
\text { about the keywords that first came to their minds. After the implementation of the word association test as a } \\
\text { pre-test, the students were given "Internet Concepts Seminar" training. The same word association test was } \\
\text { administered to the students as a post-test right after this seminar. A frequency table was created from the } \\
\text { data obtained as a result of the administration of the word association test as a pre-test and post-test. With } \\
\text { the help of this frequency table, the pre and post conceptual network maps were drawn revealing the students' } \\
\text { cognitive concepts regarding the internet. The data were analyzed and interpreted according to the } \\
\text { relationships that emerged in the pre and post concept networks. It was found as a result of the study that the } \\
\text { students intensively used the words "Facebook, Twitter, Google and Yandex" in their internet perceptions. } \\
\text { The students' responses concentrated mostly around the concepts of Social Networks and Search Engine as } \\
\text { key words. The results that were obtained indicate that there are shortcomings and misinformation in the } \\
\text { students' cognitive constructs about concepts related to the internet. }\end{array}$ \\
\hline
\end{tabular}




\section{GíRiş}

Çă̆ımızın getirmiş olduğu teknolojik gelişmeler birçok farklı alanda etkisini göstermektedir. Bu teknolojik gelişmelerden biri olarak 1990'lı yıllardan sonra hayatımıza giren internet, günümüzde insanların işlerinde, alışverişlerinde, iletişimlerinde ve eğitimlerinde kullandıkları vazgeçilmez bir araç haline gelmiştir (Aktürk ve Çiçek, 2017; Akturk ve Sahin, 2009; Akturk ve ark., 2017). İnternet, çok sayıda bilişim teknolojisi ürünü aygıtın birbirine bağlı olduğu, her yerden erişilebilen, insanların işlerini hızlı, verimli ve etkin bir şekilde yönetmelerini sağlayan, kullanımı tüm dünyada giderek artan ve durmadan genişleyerek gelişen bir iletişim ağıdır (Aktürk ve ark., 2014; Weiser, 2001). Günümüzde internetin özellikle "üretilen bilgiyi depolama, bilgiyi başkalarıyla paylaşma ve bilgiye kolayca erişme" konusunda sağlamış olduğu avantajlar (Eftekin, 2015) interneti cazip kılan özelliklerin başında gelmektedir. İnternet sayesinde insanlar çok daha rahat bir şekilde bilgiye ulaşabilme imkanına kavuşmuş durumdadır (Çalık ve Çınar, 2009). Bilgisayar ve benzeri teknolojik ürünlerin internetle birlikte kullanımının artması ile birlikte, özgür ve güvenli bir şekilde bilgiye ulaşım söz konusu olmuştur. İnternetin tüm dünyada yayılmasıyla, özellikle bilgi paylaşımı açısından gelişim yaşanmış, sanal kütüphaneler sayesinde akademik bilgilere, dergi, makale ve kitaplara ulaşmak kolaylaşmıştır (Tercan ve ark., 2012). İnternetin doğru ve etkili bir biçimde kullanımı ile, bilgiye ulaşmanın önü açılmıştır (Özbay ve Yetişener, 2000).

Günümüz şartlarında internetsiz bir eğitim düşünülemeyeceği gibi, bunun tam tersi olarak, eğitimsiz bir internet kullanımını da düşünmek pek mümkün olamamaktadır. İnternetteki içerikler eğitim sistemi içerisinde kullanılırken, internet teknolojisini geliştirmek ve ilerletmek için de eğitim gereklidir. Eğitim ile internet arasındaki ilişkiyi inceleyen araştırmalar da bu ilişkiyi desteklemektedir (Güzel, 2006). Son yıllarda gelişen teknolojilerin eğitim-öğretim ortamlarına entegrasyonu ile öğretmenlerin rollerinde de değişimler yaşanmıştır. Öğretmenler, artık öğrencilerine sadece bilgiyi aktaran değil, bunun yanında bilgiye nasıl ulaşacaklarını ve ulaştıkları bilgiyi nasıl yorumlayacaklarını da öğreten bir rehber konumunda olmalıdırlar. Böylece, özellikle internetin nasıl kullanılacağının öğretilmesi de öğretmenlerin görevleri arasına girmiştir (Akkoyunlu, 2002). Öğrencilerin internete karşı fikir ve davranışları, internetin etkin bir eğitim aracı olarak kullanmasında direkt olarak etkili olduğunu göstermektedir. Aynı zamanda öğretmenlerin de, internetin kullanımında dersler ile ilgili içerik elde etmek, kaynaklara ulaşmak ve çalışma şekilleri konularında ögrencilerini doğru internet kaynaklarına yönlendirmeleri gerekmektedir (Karal ve Şimşek, 2006).

Öğrencilerin internet kullanmada sorunlar yaşadığı ve doğru kullanımda güçlükler çektikleri bilinmektedir. Öğrencilere, internet kullanımlarında yasaklar konulması, korumacı şekilde olan yaklaşım biçimlerinin uygulanması yerine daha çok yapıcı ve bilgi verici eğitimlerin verilmesi gerekmektedir. Yasaklardan ziyade öğrencilerin karşılaşabilecekleri olumsuz yönler hakkında yapıcı olarak eğitim verilmesi internet kullanımlarında faydalı olacaktır (Binark ve Bek, 2010). Yasaklayıcı internet anlayışı sonucunda, internet kullanımında maliyetlerin artması, güncel olmayan eski ve telif hakkı olmayan yazılımların kullanılması, bilgi edinme yanlışlıkları, kalite eksiliği ve zararlı içeriklerin kullanılması gibi sorunlar ortaya çıkmaktadır (Altan, 2007). İnternetin, eğitimde düzensiz kullanımının öğrenci verimliliğini azalttığının bilim insanları tarafından belirlenmesi, teknolojinin eğitim sistemleri içerisinde etkin kullanımı konusunda çalışmaların yapılması gerekliliğini ortaya koymaktadır. Eğitim planlarının her aşamasında günün şartlarına uygun olarak, eğitim sistemlerinin hazırlanmasında ve uygulanmasında, rekabet koşullarına uygun olarak teknolojiden ve de internetten faydalanmak gerekmektedir (Özen ve ark., 2004).

İnternet çağı olarak nitelendirilen günümüzde yaşayan öğrencilerin internet hakkındaki bilgi ve beceri seviyelerini geliştirebilmek için öncelikle onların internete yönelik algılarının açığa çıkarılması gerekmektedir. Durum tespiti yapıldıktan sonra geliştirilmesi gereken alanlarda öğrencilerin eğitilmesi daha uygun olmaktadır. İnternetin yoğun olarak kullanılmasından dolayı, öğrencilerin internet kullanım bilgi düzeylerinin ve internete yönelik tutumlarının belirlenmesi, eğitimde internet kullanımı sürecinin etkili olması ve verimliliğinin arttırılması açısından önem taşımaktadır. Bu nedenle öğrencilerin internet algılarının belirlenmesi ve hangi faktörlerin etkili olduğunun ortaya çıkarılması gerekmektedir. Bu amaçla bu çalışmada 
lise öğrencilerinin internet algıları kelime ilişkilendirme testi yardımıyla tespit edilerek internet ile ilgili zihinlerindeki kavramlar arasındaki ilişkilerin nasıl oluştuğu belirlenmeye çalışılmıştır.

Son yıllarda eğitimde oluşturmacı yaklaşımın yayılması ile birlikte, zihinsel yapılardaki algıların durumunu belirlemede, değişim süreçlerini ölçmede ve oluşabilecek kavram yanılgılarını azaltma da eski yöntemler yerini yeni yöntemlere devretmiştir (Ercan ve ark., 2010). Bu duruma ilişkin bazı stratejiler, kelime ilişkilendirme testi yöntemi, yapılandırılmış grid, dallanmış ağaç, kavram haritaları, kavramsal değişim metinleri, analoji, tahmin-gözlem ve açıklama olarak ifade edilmektedir. Yukarıda belirtilen stratejiler, öğrencilere, kişisel olarak veya sınıf genelinde düşüncelerini anlatma imkanı tanımaktadır. Bu yöntemlerle öğretmenlerde öğrencilerinin düşüncelerini ve ifade yeteneklerini daha iyi şekilde algılayabilmektedir. Kelime ilişkilendirme testleri sayesinde öğrencilerin zihinsel yapılarını ve kavramlar arasındaki ilişkileri çözümlemek, algılarının durumlarını tespit etmek ve yeterliliğini ölçmek gibi önemli bilgiler elde edilmektedir (Özatlı ve Bahar, 2010).

İnsanların kelimeler ve kavramlar arasındaki algılarını tespit etmek amacı ile kelime ilişkilendirme testi tekniği ortaya çıkarılmıştır. Kelime ilişkilendirme testi, öğrencilerin zihinlerinde yer etmiş olan bilgilerin ve kavramların algılarını, aralarındaki ilişkileri, ortaya çıkan bu ilişkilerin anlam derecelerini ve yeterlilik düzeylerini belirlemeye çalışan önemli bir ölçme ve de değerlendirme olarak ifade edilmektedir (Eren ve ark., 2014; Iş1klı ve ark., 2011). Kelime ilişkilendirme testi en basit şekliyle bir veya bir seri anahtar kelimenin öğrencilere neyi çağrıştırdığının sözlü veya yazılı formda istenmesidir (Ay, 2011). Kelime ilişkilendirme testleri, uzun süreli hafızadaki kavramlar arasındaki ilişkinin ve bilgi ağının yeterli olup olmadığını belirlemek için kullanılan bir yöntemdir (Bahar ve Özatlı, 2003). Verilen kavramların sadece doğru anlaşılıp anlaşılmadığı değil; bilimleri, durumları ve hatta insanları anlamak için de uygulanmaktadır (Çardak, 2009). Kelime ilişkilendirme testinde bağımsız kavramlar, öğrencilerin zihinsel yapısını ve bu yapılarındaki kelimeler ve de kavramlar arasındaki bağları, özetle bu kelime ve kavramlarla ilgili algılar arasındaki ilişkilerin durumunu anlamak amacıyla kullanılan en çok kullanılan yöntemlerden biridir (Ekici ve Kurt, 2014; Eren ve ark., 2014).

Alanyazın incelendiğinde öğrencilerin internet ile ilgili algılarını ortaya koymak için bazı metaforik çalışmaların yürütüldüğü (Ersoy ve Türkkan, 2009; Senyuva ve Kaya, 2013; Şahin ve Baturay, 2013), ancak öğrencilerin internet ile ilgili zihinlerindeki kavramlar arasındaki ilişkileri ortaya çıkararak internet algılarını ortaya koyan bir çalışmanın olmadığı görülmüştür. Yine alanyazında kelime ilişkilendirme testi kullanarak öğrencilerin Atatürk İlkeleri (Bahar ve Kılıç, 2001; Işıklı ve ark., 2011), bilişim teknolojileri (Eren, 2012), boşaltım sistemleri (Özatlı ve Bahar, 2010), ekosistem ekolojisi (Güneş ve Gözüm, 2013), genetik (Bahar ve ark., 1999), güneş enerjisi (Aladağ ve ark., 2018), güneş sistemi (Ercan ve ark., 2010), kuraklık (Akış ve Kaya, 2018), mühendislik (Kızılay, 2018) ve müzik öğretmeni (Kurtaslan ve ark., 2018) kavramları hakkındaki zihinsel yapılarının ve kavramsal yanılgılarının belirlenmeye çalışıldığı araştırmalar mevcutken internet kavramı ile ilgili bir araştırmaya rastlanılmamıştır.

\section{Araştırmanın Amacı}

$\mathrm{Bu}$ çalışmanın amacı, internet konusunda lise öğrencilerinin algılarının tespit edilmesi ve internet ile ilgili zihinlerindeki kavramlar arasındaki ilişkilerin hangi faktörlerden oluşturduklarını belirlemektir. Araştırmanın amacı doğrultusunda problem cümlesi "Lise öğrencilerinin internet hakkındaki algıları nasıldır?" şeklinde düzenlenmiştir.

Araştırmanın problemine cevap bulabilmek için aşağıdaki alt problemler oluşturularak öğrencilerin Web Tarayıcısı, Köprü/Bağlantı (Link), Arama Motoru, Upload-Download, Online Eğitim, Online Alışveriş, Sosyal Ağlar, Online Oyun, Güvenli İnternet, Siber Zorbalık, İnternet Etiği ve Lisanslı Yazılım anahtar kavramlarıyla ilgili algıları öğrenilmeye çalışılmıştır. Kelime ilişkilendirme testinin çalışma grubu öğrencilerine ön test ve son test olarak uygulanması sonucunda şu sorulara cevap 
aranmıştır:

1. Öğrencilerin ön cevap kelime sayıları ile son cevap kelime sayıları arasında farklılık var midir?

2. Öğrencilerin ön cevap kelime çeşitleri ile son cevap kelime çeşitleri arasında farklılık var midir?

3. Öğrencilerin ön kavram ağı haritaları ile son kavram ağı haritaları arasında farklılık var mıdır?

\section{YÖNTEM}

\section{Araştırmanın Modeli}

Araştırmamızda, bireylerin duygu ve düşüncelerini ortaya çıkarmada etkili olan nitel araştırma modeli kullanılmıştır. Nitel araştırmalar özellikle sosyal olaylar ve psikolojik durumlarla ilgili nicel araştırmalara göre daha derinlemesine bilgi vermektedir. Geleneksel araştırma metotlarıyla ifade edilmesi güç olan sorulara cevap aramada nitel araştırmalar daha sık olarak kullanılmaktadır (Büyüköztürk ve ark., 2011). Nitel araştırma desenlerinden birisi olan olgu bilim (fenomenoloji) bireylerin bakış açıları ele alınarak deneyimlerinin çalışılması şeklinde tanımlanmaktadır (Kuzu, 2013). Olgu bilim deseni, farkında olunan ama tam olarak kavrayamadı ̆̆ımız olguları araştırmayı amaçlayan çalışmalar için uygun bir araştırma zemini oluşturmaktadır (Yıldırım ve Şimşek, 2006). Bu çalışmada da lise öğrencilerinin internet ile ilgili algıları incelenmiştir.

\section{Araştırmanın Katılımcıları}

Araştırmanın katılımcıları uygun örnekleme yöntemine uygun olarak 2012-2013 eğitim-öğretim yılında Konya ili merkezinde bulunan bir Anadolu Ticaret Meslek Lisesi'nde öğrenim gören öğrenciler arasından belirlenmiştir. Uygun örnekleme yöntemi, bir araştırmanın amacı doğrultusunda hedeflenen grup üyeleri arasından kolay ulaşılabilen, yakın çevrede bulunabilen ve istenilen zamanda iletişime geçilebilen gönüllü bireylerden çalışma grubunu oluşturmaya dayanan bir örnekleme yöntemidir (Büyüköztürk ve ark., 2011; Cohen ve ark., 2013).

Araştırmaya katılımı hedeflenen "Bilişim Teknolojileri", "Gazetecilik", "Muhasebe ve Finansman" ve "Radyo Televizyon" alanlarında öğrenim görmekte olan 9, 10, 11 ve 12. sınıf öğrencilerinin toplam sayıs1 635 kişi olarak belirlenmiştir. Bu öğrencilereden 475'i araştırmaya katılmıştır.

\section{Veri Toplama Araci}

Araştırmada veri toplama aracı olarak kelime ilişkilendirme testi kullanılmıştır. Testi oluşturmak için internet kavramıly ilgili, konunun üzerine inşa edildiği ve konu için önemli olduğu düşünülen 16 kavram seçilmiştir. Bu kavramlar "Web Tarayıcısı, Köprü/Bağlantı (Link), Arama Motoru, Web Sayfası, Upload-Download, Online Eğitim, Online Alışveriş, Sosyal Ağlar, Online Oyun, E-Bankacılık, E-Kütüphane, Güvenli İnternet, Siber Zorbalık, İnternet Etiği, Elektronik İmza ve Lisanslı Yazılım” olarak belirlenmiştir. Testin oluşturulma esnasında 4 uzmandan görüş alınmıştır. Daha önce konu ile ilgili çalışma yapmış 3 öğretim üyesi ve 1 doktora yapmakta olan ve bu alanda tez yazmış olan Bilişim Teknolojileri öğretmeninin görüşlerine başvurulmuştur. Uzmanların 4'ünün de konu ile ilgili seçilen 12 kavramı uygun görmesiyle Web Tarayıcısı, Köprü/Bağlantı (Link), Arama Motoru, Upload-Download, Online Eğitim, Online Alışveriş, Sosyal Ağlar, Online Oyun, Güvenli İnternet, Siber Zorbalık, İnternet Etiği ve Lisanslı Yazılım kavramları araştırmada kullanılan anahtar kavramlar olarak belirlenmiştir. Bunun dışında kalan 4 kavram (web sayfası, e-bankacılık, e-kütüphane ve elektronik imza) kelime ilişkilendirme testinden çıkarılmıştır.

Daha sonra her bir anahtar kavram bir sayfaya gelecek şekilde ve istenilen cevap sayısı kadar yani 5 kere alt alta yazılarak ve alt kısmına ilgili cümle kısmı eklenerek test düzenlenmiştir. Her sayfanın sonuna kadar anahtar kavramların tekrar edilmesi zincirleme cevap riskini önlemektedir. Öğrenci her kavram yazımında anahtar kavrama dönmezse o yazdığı kavramla ilgili kelimeler yazacaktır. Bu da testin amacı dışına çıkmasına engel olacaktır (Bahar ve Özatlı, 2003). Kelime ilişkilendirme testinin uygulama aşamasında anahtar kavram 
ile ilgili cümle yazılmasına dikkat gösterilmiş ve verilerin analizi aşamasında yazılan bu cümleler tek tek incelenmiştir. Bu sayede anahtar kelimelerle ilgili anlamlı ilişkisi olmayan kavramların çağrışım yapmasının azaltılması hedeflenmektedir. Kavram yanılgılarını azaltmak amacı ile ön test ve son test arasında öğrencilere “İnternet Kavramları Semineri” verilmiştir. Araştırmanın uygulaması, öğrencilere gerekli açıklamalar ve örnekler verildikten sonra yapılmıştır.

\section{Verilerin Toplanması}

Gerekli resmi izin ve onaylar alınarak Konya ili merkezinde bulunan bir Anadolu Ticaret Meslek Lisesi'nde ilgili müdür yardımcısı ile birlikte bölümler, sınıf mevcutları, öğrenci sayıları ve ders programları hakkındaki bilgilere dayanarak ön test, eğitim süreci ve son test aşamalarına ait süreci planlanmıştır. Planlama yapılırken öğrencilerin devam durumları, staj günleri, ders saatleri, alan derslerinin olduğu saatler gibi faktörler göz önünde bulundurulmuştur. Okul yönetiminden öğrencilere ait alınan bilgilere dayanarak öğrencilere uygulanacak olan ön test ve son teste ait dokümanların fotokopi ile çoğaltılması, kelime ilişkilendirmeye ait dokümanların kesilmesi ve sınıf mevcutlarına göre ayrılarak hazırlanması sağlanmıştır. Daha sonra sırasıyla kelime ilişkilendirme ön testinin öğrencilere uygulanması, öğrencilere internet kavramları seminerinin verilmesi ve kelime ilişkilendirme son testinin öğrencilere uygulanması aşamaları sırasıyla gerçekleştirilmiştir.

\section{Kelime ilişkilendirme ön testi uygulama süreci}

Okul yönetimi ve ders öğretmenleri ile öğrencilerin uygun olduğu zaman diliminde planlanan uygulamanın gerçekleşmesi aşamasında ilk olarak ön test kısmına ait olan demografik bilgilerin yer aldığı tek sayfadan oluşan soruları içeren anket formu dağıtılmış ve sonrasında toplanmıştır. Ön test aşamasında öğrencilerin anahtar kavramlara ait algılarını ölçmek amacıyla önceden uzman görüşü alınarak hazırlanan anahtar kavramlara ait kelime ilişkilendirme testindeki ilk anahtar kavram olan Web Tarayıcısı anahtar kavramı kesilmiş formdaki fotokopilerini sınıf ortamında öğrencilere dağıtılmıştır. Öğrencilerin kelimelere karşı hafızasındaki algıları ve bununla ilgili bir cümle kurmaları için 60 saniye süre verilmiştir. Bu süre zarfında çok fazla düşünmeden akıllarına gelen ilk kelimeleri ve ilgili cümleyi yazmalarını istenmiştir. 60 saniye sonrasında ilk anahtar kavram olan Web Tarayıcısı anahtar kavramına ait öğrencilerin zihinlerinde canlanan kelimeleri ve cümleleri ifade ettikleri ön test formları toplanmıştır. Daha sonra diğer anahtar kavramlar olan Köprü/Bağlantı (Link), Arama Motoru, Upload-Download, Online Eğitim, Online Alışveriş, Sosyal Ağlar, Online Oyun, Güvenli İnternet, Siber Zorbalık, İnternet Etiği ve Lisanslı Yazılım anahtar kavramları ile bu işlemler her defasında tekrarlanmıştır. Bu işlemler sonrasında sınıftaki her bir öğrenciye ait demografik bilgilerinin yer aldığı bir sayfalık form ve her bir öğrencinin zihnindeki algıya ait doldurmuş olduğu 12 adet kelime ilişkilendirme testi formu elde edilmiştir. Bu işlem daha önceden belirlenen çalışma grubundaki diğer bölümler ve sınıflar için tekrar edilerek tüm öğrencilerden ön testi oluşturan algılara ait veriler toplanmıştır. Bu süre zarfında işlem yapıldıktan sonra her kelime için bu işlem tekrarlanarak kelimelere ait testler sırasıyla dağıtılmış, süre verilmiş ve toplanmıştır.

\section{Internet kavramlart semineri}

Seminer içeriği ile ilgili detaylı bir literatür çalışması ve uzman görüşü alınarak içeriğe ait bir sunum hazırlama süreci takip edilmiştir. Sunum ile ilgili olarak öncesinde internet kavramını tanıtılması daha sonra ise internet kavramının kategorileri şeklinde yer alan alt başlıklarının tanıtması düşünülmüştür (Şekil 1). Seminer içeriği ile ilgili oluşturulan sunum dosyası Bilgisayar ve Öğretim Teknolojileri Eğitimi Bölümünde görevli, 2 Doçent ve 2 Dr. Öğretim Üyesi olmak üzere toplam 4 uzmanın görüşüne sunulmuştur. Uzmanların vermiş oldukları dönütler neticesinde seminer sunusuna son hali verilmiştir. Seminer sürecinde öğrencilere Web Tarayıcısı, Köprü/Bağlantı (Link), Arama Motoru, Upload-Download, Online Eğitim, Online Alışveriş, Sosyal Ağlar, Online Oyun, Güvenli İnternet, Siber Zorbalık, İnternet Etiği ve Lisanslı Yazılım anahtar kavramları hakkında detaylı bilgi verilmiştir. 
Konya ili Anadolu Ticaret Meslek Lisesi Bilişim, Gazetecilik, Muhasebe Finansman ve Radyo Televizyon bölümünde öğrenim gören 9, 10, 11 ve 12. Sınıf öğrencisi, toplam 473 kişiye araştırmacı tarafından verilen seminer her sınıf için ayrı ayrı olarak, ikişer ders saatinde oturumlar halinde verilmiştir. Bu süreçte öğrencilerin kavram yanılgılarının giderilmesi için dersler soru-cevap yöntemi kullanılarak, örnekler verilerek ve görsellerle desteklenerek işlenmiştir. Seminer sürecindeki eğitim konularını gösteren ifadeler Şekil 1'de verilmektedir.

\section{Şekil 1.}

Internet kavramının alt başlıkları

\section{INTERNET}

Teknik
• Web
tarayıcısı(browser)
- Köprü/bağlantı
(link)
- Arama motoru
- Upload - Download
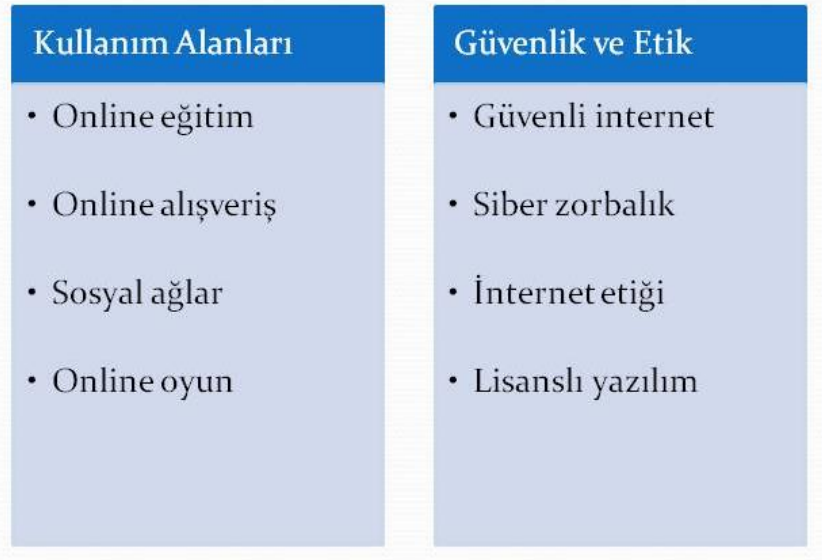

\section{Son test uygulama süreci}

Seminer eğitimlerinin ardından, öğrencilerin bilgi düzeylerindeki farklılıkları ölçmek için son test aşamasına geçilmiştir. Son test aşamasında bir ders saati boyunca ön testte verilmiş olan kelime ilişkilendirme testleri tekrar öğrencilere uygulanmıştır. Bu aşamada öğrencilerin her bir anahtar kavrama ilişkin cümle kurmaları için yine 60 saniye süre verilmiştir. Bu süre zarfında işlem yapıldıktan sonra her kelime için bu işlem tekrarlanarak kelimelere ait testler sırasıyla dağıtılmış, süre verilmiş ve toplanmıştır. Her bir öğrencinin zihnindeki algıya ait doldurmuş olduğu 12 adet kelime ilişkilendirme testi elde edilmiştir. Bu işlem yukarıdaki belirtilen tüm bölümler ve sınıflar için tekrar edilerek son testlere ait veriler toplanmıştır.

\section{Verilerin Analizi}

Araştırmada, kelime ilişkilendirme testi kullanılarak elde edilen verilerin analizinde nitel veri analizi teknikleri içinde kabul edilen betimsel analiz kullanılmıştır. Anahtar kavramların analizi ile elde edilen en fazla tekrarlanan cevap kavramlar, cevap kavramların kendi içinde dağılımı, anahtar kavramlara toplamda kaç farklı cevap verildiği yanıtlarından hareketle oluşturulan frekans yüzde tabloları çıkarılmıştır. Cevap kavramlardan elde edilen bulgulara göre kavram ağları kesme noktalarına göre oluşturulmuştur. Kesme noktaları tekniği ile kelime ilişkilendirme testlerinde bulunan anahtar kavramlar için en fazla cevap verilen kelimelere göre kesme noktaları oluşturulmuştur. Bu cevaplar, kavram ağının ilk kısmındaki bölümle yazılarak ifade edilmektedir. Kesme noktaları belirli aralıklarla aşağıya doğru yazılmakta ve tüm anahtar kelimeler kavram ağlarında yer bulana kadar işlem devam etmektedir. Araştırmada kullanılan kesme noktası aralıkları ve renkleri aşağıda belirtilmektedir.

- Ön test sonuçlarına göre kesme noktası 300-400 aralığında yeşil renk ile ifade edilmiştir.

- Ön test sonuçlarına göre kesme noktası 200-300 aralığında koyu sarı renk ile ifade edilmiştir. 
- Ön test sonuçlarına göre kesme noktası 100-200 aralığında bordo renk ile ifade edilmiştir.

- Ön test sonuçlarına göre kesme noktası 50-100 aralığında açık mavi renk ile ifade edilmiştir.

- Ön test sonuçlarına göre kesme noktası 0-50 aralığında turuncu renk ile ifade edilmiştir.

- Son test sonuçlarına göre kesme noktası 400 ve üzeri lacivert renk ile ifade edilmiştir.

- Son test sonuçlarına göre kesme noktası 300-400 aralığında yeşil renk ile ifade edilmiştir.

- Son test sonuçlarına göre kesme noktası 200-300 aralığında koyu sarı renk ile ifade edilmiştir.

- Son test sonuçlarına göre kesme noktası 100-200 aralığında bordo renk ile ifade edilmiştir.

- Son test sonuçlarına göre kesme noktası 50-100 aralığında açık mavi renk ile ifade edilmiştir.

- Son test sonuçlarına göre kesme noktası 0-50 aralığında turuncu renk ile ifade edilmiştir.

Araştırmada ön test ve son test olarak kullanılan kelime ilişkilendirme testinin sonuçlarını değerlendirmek amacıyla anahtar kavramlara verilen cevapların hepsi ayrıntılı bir şekilde incelenmiştir. Ön test ve son testte hangi anahtar kavram için hangi kelimelerin ya da kavramların kaçar defa tekrarlandığını gösteren frekans tabloları oluşturulmuştur. Oluşturulan bu frekans tablosu temel alınarak kavram ağları oluşturulmuştur.

Araştırmanın çalışma grubunda olup da bazı nedenlerden ötürü kelime ilişkilendirme ön testi, internet kavramları semineri ve kelime ilişkilendirme son testinden herhangi birisine katılamayan öğrencilerin verileri analiz kapsamına alınmamıştır. Bunun yanında çalışma grubundaki bazı öğrencilerin kelime ilişkilendirme testlerine alaycı bir tutumla cevap vermeleri, kelimelere hep aynı cevabı tekrar etmeleri, hiç cevap vermemeleri gibi nedenlerle bu öğrencilerden de elde edilen veriler analize dahil edilmemiştir.

\section{BULGULAR}

\section{Araştırmanın Birinci Alt Problemine İlişkin Bulgular}

Araştırmanın birinci alt problemi olan "Kelime ilişkilendirme testinin çalışma grubu öğrencilerine ön test ve son test olarak uygulanması sonucunda öğrencilerin ön cevap kelime sayıları ile son cevap kelime sayıları arasında farklılık var mıdır?" sorusuna ilişkin öğrencilerin Web Tarayıcısı, Köprü/Bağlantı (Link), Arama Motoru, Upload-Download, Online Eğitim, Online Alışveriş, Sosyal Ağlar, Online Oyun, Güvenli İnternet, Siber Zorbalık, İnternet Etiği ve Lisanslı Yazılım anahtar kavramları ile ilgili ön cevap kelime sayıları ile son cevap kelime sayıları Tablo 1'de gösterilmiştir.

\section{Tablo 1.}

Anahtar kavramlara verilen ön cevap kelime sayıları ile son cevap kelime sayıları

\begin{tabular}{lccc}
\hline ANAHTAR KAVRAMLAR & ÖN CEVAP KELIME SAYISI & SON CEVAP KELIME SAYISI & TOPLAM \\
\hline Web Tarayıcısı & 2213 & 2119 & 4332 \\
Köprü/Bağlantı Link & 2234 & 2115 & 4349 \\
Arama Motoru & 2249 & 2130 & 4379 \\
Upload-Download & 2228 & 2123 & 4351 \\
Online Eğitim & 2221 & 2105 & 4326 \\
Online Alışveriş & 2233 & 2138 & 4371 \\
Sosyal Ağlar & 2233 & 2121 & 4354 \\
Online Oyun & 2240 & 2132 & 4372 \\
Güvenli İnternet & 2220 & 2117 & 4337 \\
Siber Zorbalık & 2223 & 2113 & 4336 \\
Internet Etiği & 2215 & 2096 & 4311 \\
Lisanslı Yazılım & 2224 & 2118 & 4342 \\
\multicolumn{1}{c}{ Genel Toplam } & 26733 & 25427 & 52160 \\
\hline
\end{tabular}

Öğrencilerin anahtar kavramlara verdikleri ön cevap sayılarında en çok Arama Motoru (2249) anahtar kelimesine ilişkin, en az ise Web Tarayıcısı (2213) anahtar kavramına ilişkin cevaplar verdikleri 
görülmektedir. Öğrencilerin son cevap sayılarına bakıldığında ise en çok Online Alışveriş (2138) anahtar kavramına ilişkin, en az ise İnternet Etiği (2096) anahtar kavramına ilişkin cevaplar verdikleri görülmektedir. Öğrencilerin anahtar kavramlara verdikleri toplam cevap sayılarına bakıldığında ise kelime ilişkil endirme ön testinde 26733 adet, kelime ilişkilendirme son testinde 25427 adet cevap kelime ürettikleri tespit edilmiştir. “İnternet Kavramları Semineri” öncesi ve sonrasında her bir anahtar kavramı teker teker incelediğimizde, öğrencilerin kelime ilişkilendirme son testine göre kelime ilişkilendirme ön testinde daha fazla cevap kelime ürettikleri söylenebilir.

\section{Araştırmanın İkinci Alt Problemine İlişkin Bulgular}

Araştırmanın ikinci alt problemi olan "Kelime ilişkilendirme testinin çalışma grubu öğrencilerine ön test ve son test olarak uygulanması sonucunda öğrencilerin ön cevap kelime çeşitleri ile son cevap kelime çeşitleri arasında farklılık var mıdır?” sorusuna ilişkin öğrencilerin Web Tarayıcısı, Köprü/Bağlantı (Link), Arama Motoru, Upload-Download, Online Eğitim, Online Alışveriş, Sosyal Ağlar, Online Oyun, Güvenli İnternet, Siber Zorbalık, İnternet Etiği ve Lisanslı Yazılım anahtar kavramları ile ilgili ön cevap kelime çeşitleri ve son cevap kelime çeşitleri incelendiğinde, son cevap kelime çeşitlerinin ön cevap kelime çeşitlerine her bir kavram için üstünlük sağladığı görülmektedir. Kelime ilişkilendirme testine göre hazırlanan frekans tabloları incelendiğinde verilen cevap kelimelerin kalitesinin ve anlamlılığının kelime ilişkilendirme son testinde daha fazla olduğu görülmektedir. Her bir anahtar kavram için kelime ilişkilendirme ön testi ve son testi cevap kelimeleri aşağıdaki Tablo 2'de verilmektedir.

\section{Tablo 2.}

Anahtar kavramlara verilen toplam çeşit ve cevap sayısına ilişkin bulgular

\begin{tabular}{|c|c|c|c|c|c|c|}
\hline \multirow[b]{2}{*}{$\begin{array}{l}\text { ANAHTAR } \\
\text { KAVRAM }\end{array}$} & \multirow{2}{*}{\begin{tabular}{l}
\multicolumn{1}{c}{ ÖN TEST } \\
EN ÇOK CEVAP \\
VERİLEN İLK \\
BEŞ KELİME
\end{tabular}} & \multirow[b]{2}{*}{$\begin{array}{l}\text { ÇEŞİT } \\
\text { SAYISI }\end{array}$} & \multirow[b]{2}{*}{$\begin{array}{l}\text { CEVAP } \\
\text { SAYISI }\end{array}$} & \multicolumn{3}{|c|}{ SON TEST } \\
\hline & & & & $\begin{array}{l}\text { EN ÇOK CEVAP } \\
\text { VERİLEN İLK } \\
\text { BEŞ KELİME }\end{array}$ & $\begin{array}{l}\text { ÇEŞİT } \\
\text { SAYISI }\end{array}$ & $\begin{array}{l}\text { CEVAP } \\
\text { SAYISI }\end{array}$ \\
\hline Web Tarayıcısı & $\begin{array}{l}\text { Yandex(197), } \\
\text { Google(169), } \\
\text { Mozilla(164), } \\
\text { İnternet } \\
\text { Explorer(133), } \\
\text { Opera(105) }\end{array}$ & 39 & 2213 & $\begin{array}{l}\text { Mozilla } \\
\text { Firefox(252), } \\
\text { Google(244), } \\
\text { Yandex(224), } \\
\text { Chrome(201), } \\
\text { Opera(160) }\end{array}$ & 29 & 2119 \\
\hline $\begin{array}{l}\text { Köprü/Bağlantı } \\
\text { (Link) }\end{array}$ & $\begin{array}{l}\text { Facebook(106), } \\
\text { Boğaziçi } \\
\text { Köprüsü(75), } \\
\text { İnternet(73), } \\
\text { Meyve Suyu(46), } \\
\text { İçecek(41) }\end{array}$ & 66 & 2234 & $\begin{array}{l}\text { Facebook(79), } \\
\text { Bağlantı(74), } \\
\text { Adres(57), } \\
\text { Http(57), } \\
\text { Müzik(52) }\end{array}$ & 71 & 2115 \\
\hline Arama Motoru & $\begin{array}{l}\text { Google(361), } \\
\text { Yandex(261), } \\
\text { Facebook(114), } \\
\text { YouTube(114), } \\
\text { İnternet(88) }\end{array}$ & 36 & 2249 & $\begin{array}{l}\text { Google(373), } \\
\text { Yandex(347), } \\
\text { Yahoo(144), } \\
\text { Mozilla } \\
\text { Firefox(103), } \\
\text { Bing(101), }\end{array}$ & 28 & 2130 \\
\hline $\begin{array}{l}\text { Upload- } \\
\text { Download }\end{array}$ & $\begin{array}{l}\text { İndirmek(177), } \\
\text { Müzik(168), } \\
\text { Film(142), } \\
\text { Oyun(110), } \\
\text { Yüklemek(85) }\end{array}$ & 34 & 2228 & $\begin{array}{l}\text { Müzik-mp3(214), } \\
\text { Yüklemek(205), } \\
\text { İndirmek(152), } \\
\text { Oyun(132), } \\
\text { Film(121), }\end{array}$ & 51 & 2123 \\
\hline Online Eğitim & $\begin{array}{l}\text { Vitamin(137), } \\
\text { Eba(102), Ekol } \\
\text { Hoca(89), } \\
\text { İnternet(43), E- } \\
\text { okul(41) }\end{array}$ & 57 & 2221 & $\begin{array}{l}\text { Vitamin(168), Ekol } \\
\text { Hoca(128), } \\
\text { Eba(103), E- } \\
\text { okul(55), TTnet } \\
\text { Vitamin(36) }\end{array}$ & 70 & 2105 \\
\hline Online Alışveriş & $\begin{array}{l}\text { Gittigidiyor(155), } \\
\text { Markafoni(110), }\end{array}$ & 44 & 2233 & $\begin{array}{l}\text { Gittigidiyor(158), } \\
\text { Morhipo(122), }\end{array}$ & 49 & 2138 \\
\hline
\end{tabular}




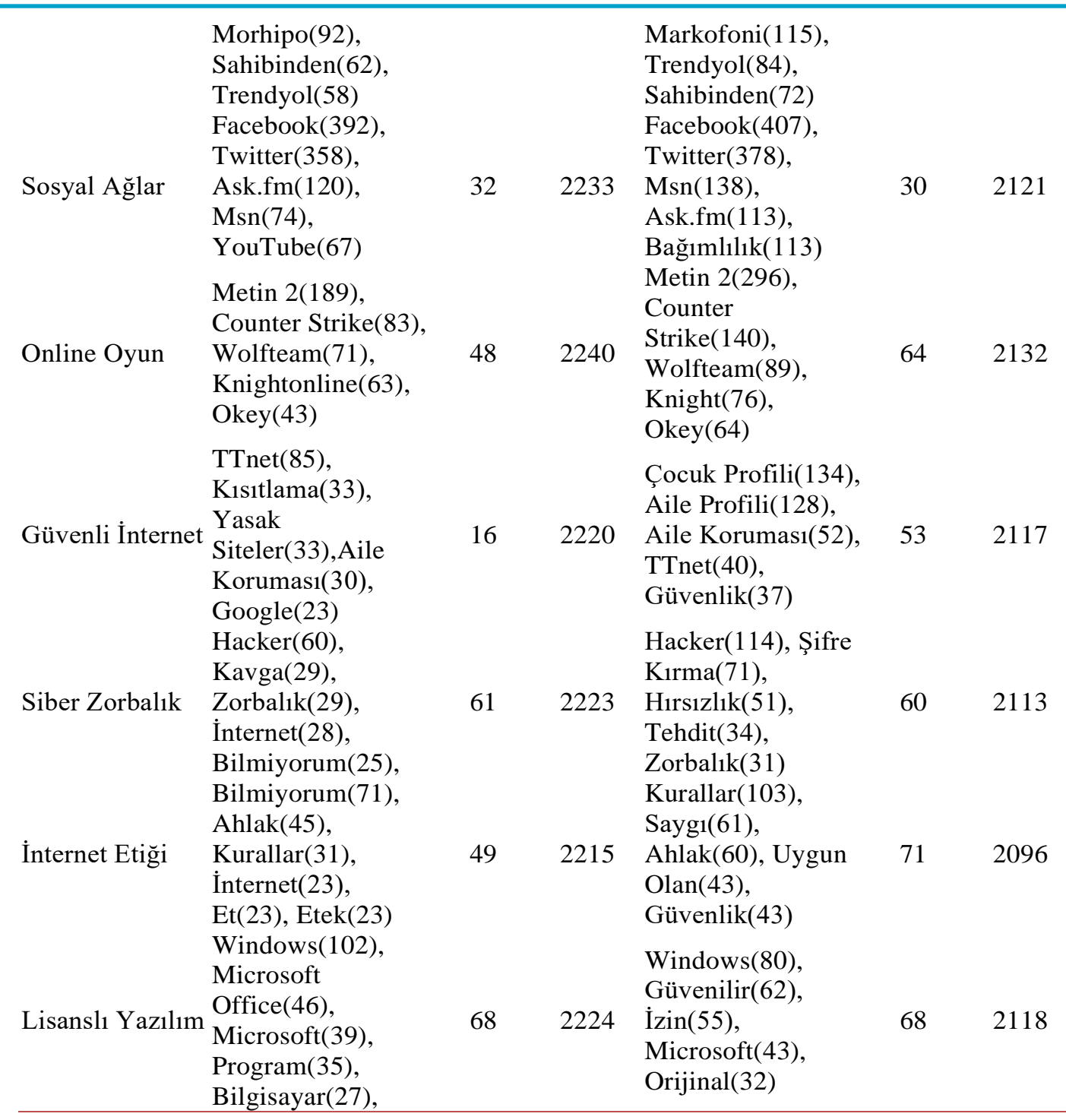

Araştırma bulguları sonucunda toplam cevap sayıları ve çeşitlerine yönelik olarak elde edilen veriler Tablo 2'de gösterilmektedir. Bu verilerle oluşturulan tabloda anahtar kavramlara ilişkin olarak verilmiş olan cevap çeşitleri ile cevap sayıları ve anahtar kavramlara verilen en çok cevap çeşitlerinin ilk 5 tanesi gösterilmektedir. Tablo 2'yi incelediğimizde, ön test aşamasında öğrenciler tarafından anahtar kavramlara ilişkin verilen cevap sayıları ve cevap çeşitleri ile anahtar kavramlar için en çok kullanılmış olan ilk beş cevaplar şu şekilde olmuştur:

- Web Tarayıcısı anahtar kavramına öğrenciler tarafından 2213 adet cevap verilmiş, 39 adet cevap çeşidi sonucuna ulaşılmıştır. Bu anahtar kavramda en çok kullanılan cevap kelimeler sırası ile Yandex(197), Google(169), Mozilla(164), İnternet Explorer(133), Opera(105) olmuştur.

- Köprü/Bağlantı (Link) anahtar kavramına, öğrenciler 2234 cevap sayısı ile karşılık vermiş ve 66 cevap çeşidi tespit edilmiştir. Facebook(106), Boğaziçi Köprüsü(75), İnternet(73), Meyve Suyu(46), İçecek(41) kelimeleri en çok cevap verilen ilk beş kelime olmuştur.

- Arama Motoru anahtar kavramına, öğrenciler 2249 cevap sayısı ile karşı1ık vermiş ve 36 cevap çeşidi tespit edilmiştir. Google(361), Yandex(261), Facebook(114), YouTube(114), İnternet(88) cevapları ise en çok kullanılan kelimeler olmuştur.

- Upload-Download anahtar kavramına öğrenciler tarafindan 2228 adet cevap verilmiş, 34 adet cevap çeşidi sonucuna ulaşılmıştır. Bu anahtar kavramda en çok kullanılan cevap kelimeler sırası ile İndirmek(177), Müzik(168), Film(142), Oyun(110), Yüklemek(85) olmuştur. 
- Online Eğitim anahtar kavramına, öğrenciler 2221 cevap sayısı ile karşılık vermiş ve 57 cevap çeşidi tespit edilmiştir. Vitamin(137), Eba(102), Ekol Hoca(89), İnternet(43), E-okul(41) cevapları ise en çok kullanılan kelimeler olmuştur.

- Online Alışveriş anahtar kavramına öğrenciler tarafindan 2233 adet cevap verilmiş ve 44 adet cevap çeşidi sonucuna ulaşılmıştır. Bu anahtar kavramda en çok kullanılan cevap kelimeler sırası ile Gittigidiyor(155), Markafoni(110), Morhipo(92), Sahibinden(62), Trendyol(58) olmuştur.

- Sosyal Ağlar anahtar kavramına, öğrenciler 2233 cevap sayısı ile karşılık vermiş ve 32 cevap çeşidi tespit edilmiştir. Facebook(392), Twitter(358), Ask.fm(120), Msn(74), YouTube(67)cevapları ise en çok kullanılan kelimeler olmuştur.

- Online Oyun anahtar kavramına öğrenciler tarafından 2240 adet cevap verilmiş, 48 adet cevap çeşidi sonucuna ulaşılmıştır. Bu anahtar kavramda en çok kullanılan cevap kelimeler sırası ile Metin 2(189), Counter Strike(83), Wolfteam(71), Knightonline(63), Okey(43)olmuştur.

- Güvenli İnternet anahtar kavramına, öğrenciler 2220 cevap sayısı ile karşılık vermiş ve 16 cevap çeşidi tespit edilmiştir. TTnet(85), Kısıtlama(33), Yasak Siteler(33), Aile Koruması(30), Google(23) cevapları ise en çok kullanılan kelimeler olmuştur.

- Siber Zorbalık anahtar kavramına öğrenciler tarafından 2223 adet cevap verilmiş, 61 adet cevap çeşidi sonucuna ulaşılmıştır. Bu anahtar kavramda en çok kullanılan cevap kelimeler sırası ile Hacker(60), Kavga(29), Zorbalık(29), İnternet(28), Bilmiyorum(25)olmuştur.

- İnternet Etiği anahtar kavramına, öğrenciler 2215 cevap sayısı ile karşı1ık vermiş ve 49 cevap çeşidi tespit edilmiştir. Bilmiyorum(71), Ahlak(45), Kurallar(31), İnternet(23), Et(23), Etek(23)cevapları ise en çok kullanılan kelimeler olmuştur.

- Lisanslı Yazılım anahtar kavramına öğrenciler tarafından 2224 adet cevap verilmiş, 68 adet cevap çeşidi sonucuna ulaşılmıştır. Bu anahtar kavramda en çok kullanılan cevap kelimeler sırası ile Windows(102), Microsoft Office(46), Microsoft(39), Program(35), Bilgisayar(27), olmuştur.

Diğer taraftan Tablo 2'yi son testte öğrenciler tarafından anahtar kavramlara yönelik olarak verilen cevaplar açısından incelediğimizde, cevap sayıları ve cevap çeşitleri ile anahtar kavramlar için en çok kullanılmış olan ilk beş cevaplar şu şekilde olmuştur:

- Web Tarayıcısı anahtar kavramına öğrenciler tarafından 2119 adet cevap verilmiş, 29 adet cevap çeşidi sonucuna ulaşılmıştır. Bu anahtar kavramda en çok kullanılan cevap kelimeler sırası ile Mozilla Firefox(252), Google(244), Yandex(224), Chrome(201), Opera(160) olmuştur.

- Köprü/Bağlantı (Link) anahtar kavramına, öğrenciler 2115 cevap sayısı ile karşıllı vermiş ve 71 cevap çeşidi tespit edilmiştir. Facebook(79), Bağlantı(74), Adres(57), http(57), Müzik(52) kelimeleri en çok cevap verilen ilk beş kelime olmuştur.

- Arama Motoru anahtar kavramına, öğrenciler 2130 cevap sayısı ile karşı1ık vermiş ve 28 cevap çeşidi tespit edilmiştir. Google(373), Yandex(347), Yahoo(144), Mozill Firefox(103), Bing(101) cevapları ise en çok kullanılan kelimeler olmuştur.

- Upload-Download anahtar kavramına öğrenciler tarafından 2123 adet cevap verilmiş, 51 adet cevap çeşidi sonucuna ulaşılmıştır. Bu anahtar kavramda en çok kullanılan cevap kelimeler sırası ile Müzikmp3(214), Yüklemek(205), İndirmek(152), Oyun(132), Film(121) olmuştur.

- Online Eğitim anahtar kavramına, öğrenciler 2105 cevap sayısı ile karşılık vermiş ve 70 cevap çeşidi tespit edilmiştir. Vitamin(168), Ekol Hoca(128), Eba(103), E-okul(55), TTnet Vitamin(36) cevapları ise bu anahtar kavram için en çok kullanılan kelimeler olmuştur. 
- Online Alışveriş anahtar kavramına öğrenciler tarafından 2138 adet cevap verilmiş, 49 adet cevap çeşidi sonucuna ulaşılmıştır. Bu anahtar kavramda en çok kullanılan cevap kelimeler sırası ile Gittigidiyor(158), Morhipo(122), Markofoni(115), Trendyol(84), Sahibinden(72)olmuştur.

- Sosyal Ağlar anahtar kavramına, öğrenciler 2121 cevap sayısı ile karşılık vermiş ve 30 cevap çeşidi tespit edilmiştir. Facebook(407), Twitter(378), Msn(138), Ask.fm(113), Bağımlılık(113)c evapları ise en çok kullanılan kelimeler olmuştur.

- Online Oyun anahtar kavramına öğrenciler tarafından 2132 adet cevap verilmiş, 64 adet cevap çeşidi sonucuna ulaşılmıştır. Bu anahtar kavramda en çok kullanılan cevap kelimeler sırası ile Metin 2(296), Counter Strike(140), Wolfteam(89), Knight(76), Okey(64)olmuştur.

- Güvenli İnternet anahtar kavramına, öğrenciler 2117 cevap sayısı ile karşılık vermiş ve 53 cevap çeşidi tespit edilmiştir. Çocuk Profili(134), Aile Profili(128), Aile Koruması(52), TTnet(40), Güvenlik(37) cevapları ise en çok kullanılan kelimeler olmuştur.

- Siber Zorbalık anahtar kavramına öğrenciler tarafından 2113 adet cevap verilmiş, 60 adet cevap çeşidi sonucuna ulaşılmıştır. Bu anahtar kavramda en çok kullanılan cevap kelimeler sırası ile Hacker(114), Şifre Kırma(71), Hırsızlık(51), Tehdit(34), Zorbalık(31)olmuştur.

- İnternet Etiği anahtar kavramına, öğrenciler 2096 cevap sayısı ile karşılık vermiş ve 71 cevap çeşidi tespit edilmiştir. Kurallar(103), Saygı(61), Ahlak(60), Uygun Olan(43), Güvenlik(43)cevapları ise en çok kullanılan kelimeler olmuştur.

- Lisanslı Yazılım anahtar kavramına öğrenciler tarafından 2118 adet cevap verilmiş, 68 adet cevap çeşidi sonucuna ulaşılmıştır. Bu anahtar kavramda en çok kullanılan cevap kelimeler sırası ile Windows(80), Güvenilir(62), İzin(55), Microsoft(43), Orijinal(32) olmuştur.

\section{Araştırmanın Üçüncü Alt Problemine İlişkin Bulgular}

Araştırmanın üçüncü alt problemi olan "Kelime ilişkilendirme testinin çalışma grubu öğrencilerine ön test ve son test olarak uygulanması sonucunda öğrencilerin ön kavram ağı haritaları ile son kavram ağı haritaları arasında farklılık var mıdır?” sorusuna ilişkin öğrencilerin Web Tarayıcısı, Köprü/Bağlantı (Link), Arama Motoru, Upload-Download, Online Eğitim, Online Alışveriş, Sosyal Ağlar, Online Oyun, Güvenli İnternet, Siber Zorbalık, İnternet Etiği ve Lisanslı Yazılım kavramları ile ilgili olarak verilen cevap kelimelerin sayılarına göre hazırlanmış olan kesme noktaları ve bu kesme noktalarına göre çizilen kavram ağı haritaları verilmiştir.

\section{Kesme noktası 400 ve üzeri olan cevap kelimelerden oluşturulan kavram ağı haritaları}

Kelime ilişkilendirme testinin lise öğrencilerine ön test ve son test olarak uygulanması sonucunda oluşturulan frekans tablosuna göre belirlenen ve kesme noktası 400 ve üzeri olan cevap kelimelerden oluşturulan ön kavram ağı haritaları ve son kavram ağı haritaları aşağıda verilmiştir.

\section{Ön kavram ăg haritalarl}

Araştırma verilerinden elde edilen sonuçlara göre, kesme noktası 400 ve üzeri cevap kelimelerine karşılık sonuçlar elde edilememiştir. Bu nedenle, kesme noktası 400 ve üzeri ön kavram ağı haritaları oluşturulamamıştır.

\section{Son Kavram A $\breve{g l}$ Haritaları}

Aşağıdaki Şekil-2'de kelime ilişkilendirme son testindeki anahtar kavramlara verilen cevap sayılarının 400 ve üzerinde kesme noktasına göre hazırlanmış son kavram ağı haritaları verilmektedir.

\section{Şekil 2.}


Kesme noktası 400 ve üzerine göre oluşturulmuş son kavram ă̆ haritası

Facebook

AĞLAR

Şekil 2'deki son kavram ağına göre Sosyal Ağlar anahtar kavramıyla "Facebook" cevap kelimesinin ilişkilendirildiği görülmektedir. Ön test sonrası öğrencilere verilen eğitim neticesinde verdikleri "Facebook" cevap kelimesinde artış olmuştur. Bu nedenle son test aşamasında öğrencilerin Sosyal Ağlar anahtar kelimesi için "Facebook" cevap kelimesini en çok tercih ettikleri kelime olarak belirlenmiştir.

\section{Kesme noktası 300-400 arası olan cevap kelimelerden oluşturulan kavram ağı haritaları}

Kelime ilişkilendirme testinin lise öğrencilerine ön test ve son test olarak uygulanması sonucunda oluşturulan frekans tablosuna göre belirlenen ve kesme noktası 300-400 arası olan cevap kelimelerden oluşturulan ön kavram ağı haritaları ve son kavram ağı haritaları aşağıda verilmiştir.

Ön kavram ă̆ haritaları

Aşağıdaki Şekil 3'te kelime ilişkilendirme ön testindeki anahtar kavramlara verilen cevap sayılarının 300-400 arasında kesme noktasına göre hazırlanmış ön kavram ağı haritaları verilmektedir.

Şekil 3.

Kesme noktası 300-400'e göre oluşturulmuş ön kavram ă̆ haritası

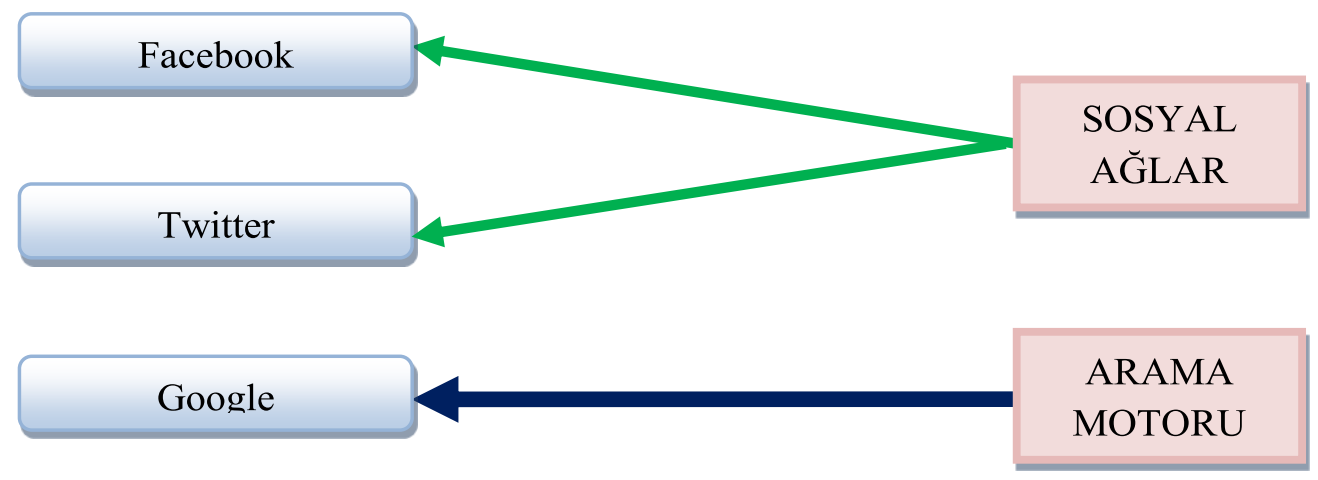

Öğrencilere yapılan kelime ilişkilendirme ön testi sonucunda, kesme noktası 300-400 arası olan cevaplara göre Sosyal Ağlar anahtar kavramına "Facebook" ve "Twitter" cevap kelimelerini kullandıkları görülmektedir. Ön test aşamasındaki "Facebook" cevap kelimesinde son testte artış olmuş ve algılarda farklılıklar ortaya çıkmıştır.

Aynı zamanda bu kesme noktaları arasında ön test sonucuna göre Arama Motoru anahtar kavramına öğrencilerin "Google" cevap kelimesini kullandıkları tespit edilmiştir.

Son kavram ăg haritaları

Aşağıdaki Şekil 4'te kelime ilişkilendirme son testindeki anahtar kavramlara verilen cevap sayılarının 300400 arasında kesme noktasına göre hazırlanmış son kavram ağı haritaları verilmektedir.

\section{Şekil 4.}

Kesme noktası 300-400'e göre oluşturulmuş son kavram ăğ haritası

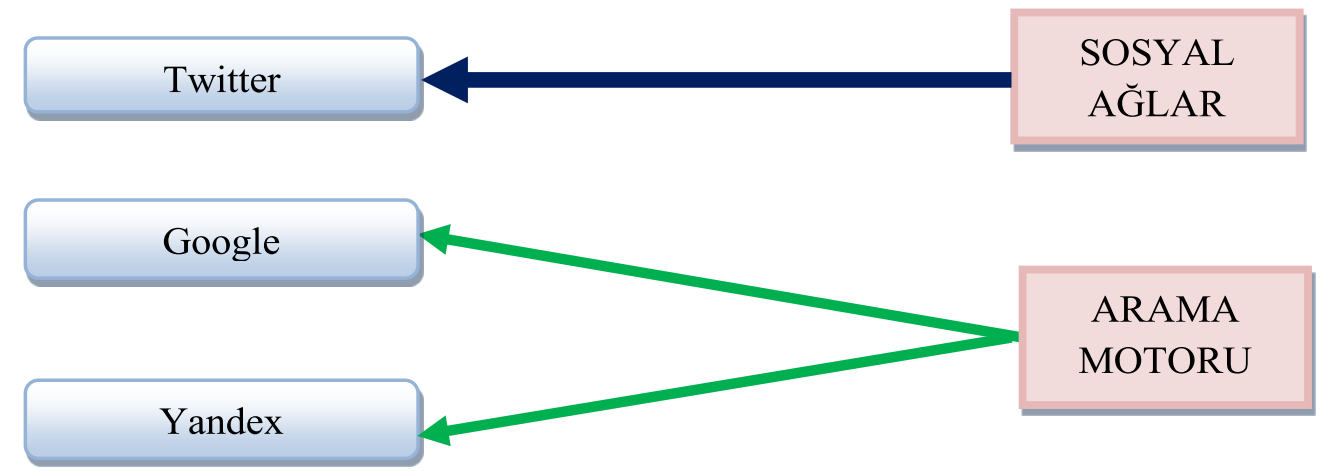


Öğrencilere konu ile ilgili olarak verilen "İnternet Kavramları Semineri" neticesinde elde edilen son test sonuçlarına göre, kesme noktası 300-400 aralığında Sosyal Ağlar anahtar kavramına "Twitter" cevap kelimesini kullanarak cevap verildiği belirlenmiştir. Yine bu aralıktaki son test sonuçlarına göre, Arama Motoru anahtar kavramına öğrencilerin "Google" cevap kelimesi ile birlikte "Yandex" cevap kelimesini kullandıkları görülmektedir.

\section{Kesme noktası 200-300 arası olan cevap kelimelerden oluşturulan kavram ağı haritaları}

Kelime ilişkilendirme testinin lise öğrencilerine ön test ve son test olarak uygulanması sonucunda oluşturulan frekans tablosuna göre belirlenen ve kesme noktası 200-300 arası olan cevap kelimelerden oluşturulan ön kavram ağı haritaları ve son kavram ağı haritaları aşağıda verilmiştir.

Ön kavram ăg haritalarl

Aşağıdaki Şekil-5'te kelime ilişkilendirme ön testindeki anahtar kavramlara verilen cevap sayılarının 200-300 arasında kesme noktasına göre hazırlanmış ön kavram ağı haritaları verilmektedir.

\section{Şekil 5.}

Kesme noktası 200-300'e göre oluşturulmuş ön kavram ă̆ı haritası

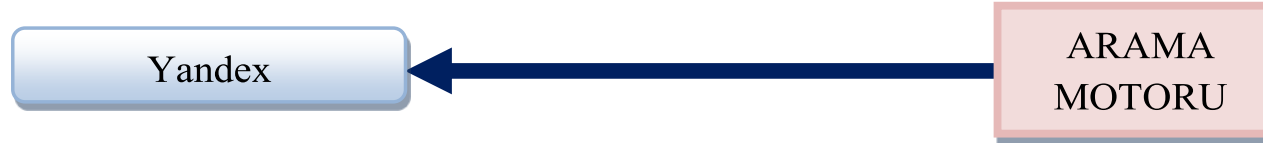

Kesme noktası 200-300 aralığında elde edilen ön test sonuçlarına göre, Arama Motoru anahtar kavramına "Yandex" kelimesi ile cevap verilmiştir.

Son kavram ăğ haritaları

Aşağıdaki Şekil 6'da kelime ilişkilendirme ön testindeki anahtar kavramlara verilen cevap sayılarının 200300 arasında kesme noktasına göre hazırlanmış son kavram ağı haritaları verilmektedir. 


\section{Şekil 6.}

Kesme noktası 200-300'e göre oluşturulmuş son kavram ă̆ı haritası

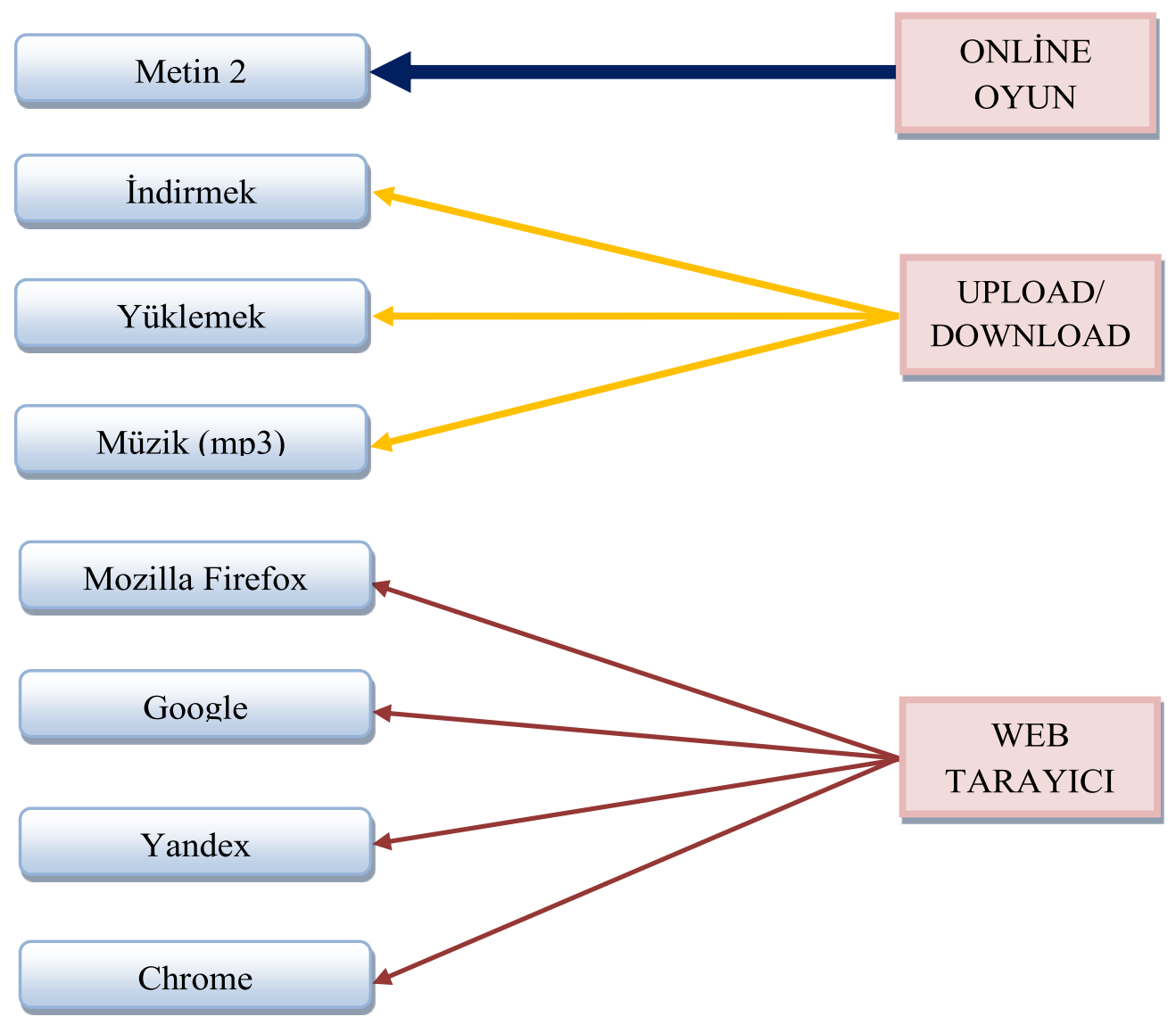

Kesme noktası 200-300 aralığında elde edilen son test sonuçlarına göre, bu öğrencilerin Online Oyun anahtar kavramına "Metin 2" cevap kelimesini, Upload-Download anahtar kavramına "İndirmek", "Müzik (mp3)" ve "Yüklemek" cevap kelimelerini; Web Tarayıcısı anahtar kavramına "Mozilla Firefox", "Google", "Yandex" ve "Chrome" cevap kelimelerini verdikleri görülmektedir.

Elde edilen son kavram ağı sonuçlarına göre öğrencilerin ön teste verdikleri cevapları ile eğitim sonrası son teste verilen cevaplar arasında farklılıklar ortaya çıkmıştır. Ön testte öğrenciler sadece Arama Motoru anahtar kavramına tek bir cevap ile karşı1lık vermişken, son teste Online Oyun, Upload-Download ve Web Tarayıcı anahtar kavramlarına sekiz farklı cevap ile karşılık vermişlerdir.

\section{Kesme noktası 100-200 arası olan cevap kelimelerden oluşturulan kavram ağı haritaları}

Kelime ilişkilendirme testinin lise öğrencilerine ön test ve son test olarak uygulanması sonucunda oluşturulan frekans tablosuna göre belirlenen ve kesme noktas1 100-200 arası olan cevap kelimelerden oluşturulan ön kavram ağı haritaları ve son kavram ağı haritaları aşağıda verilmiştir.

Ön kavram ăg haritalarl

Aşağıdaki Şekil 7'de kelime ilişkilendirme ön testindeki anahtar kavramlara verilen cevap sayılarının 100200 arasında kesme noktasına göre hazırlanmış ön kavram ağı haritaları verilmektedir. 


\section{Şekil 7.}

Kesme noktası 100-200'e göre oluşturulmuş ön kavram ă̆ haritası

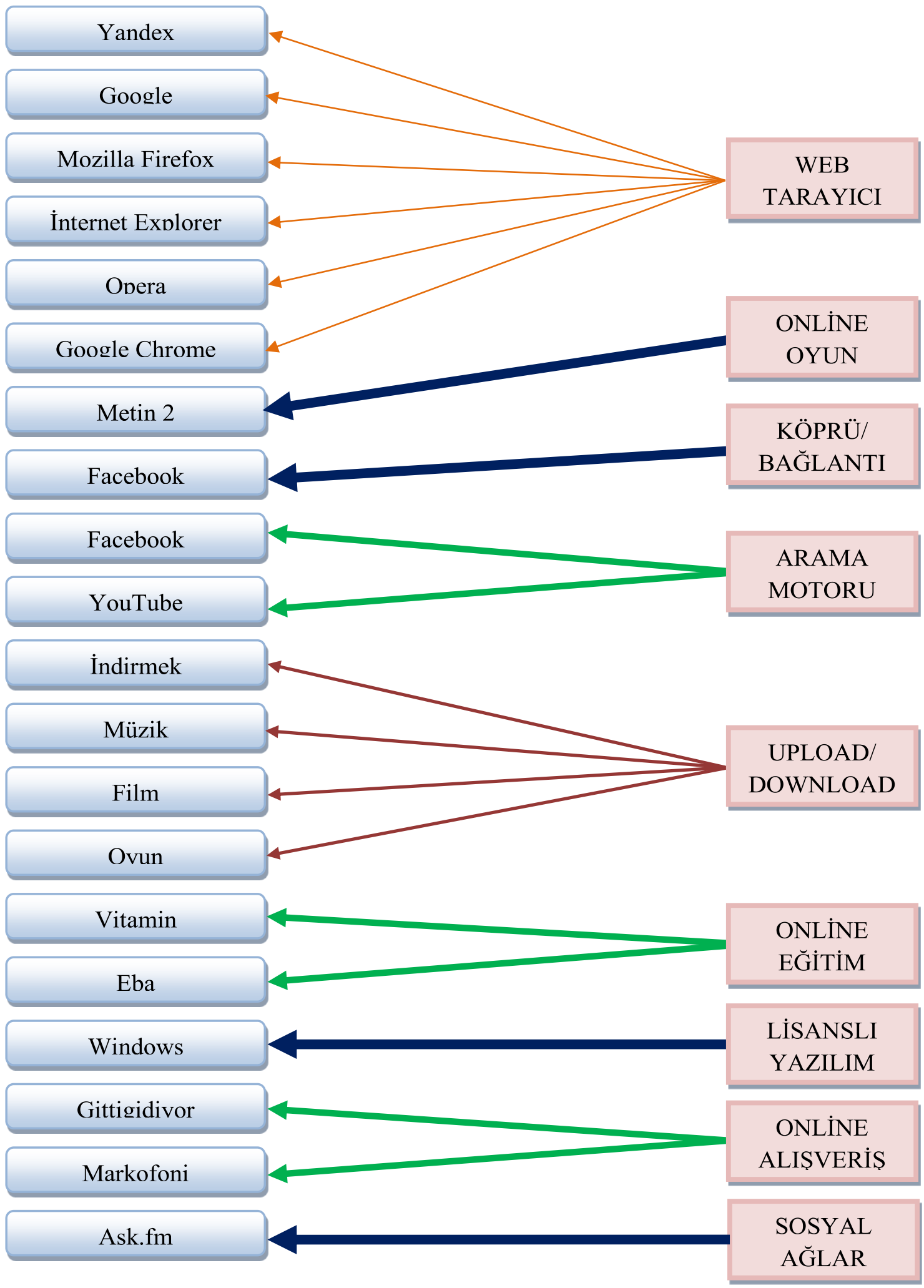

Ön kavram ağı sonuçlarına göre 100-200 kesme noktası aralığında Web Tarayıcı, Online Oyun, Köprü/Bağlantı (Link), Arama Motoru, Upload-Download, Online Eğitim, Lisanslı Yazılım, Online Alışveriş ve Sosyal Ağlar anahtar kavramları ortaya çıkmış ve sonuç olarak dokuz farklı anahtar kavram öğrenciler 
tarafından ifade edilmiştir. Bu anahtar kavramlar 20 farklı cevap kelimesi ile ifade edilirken, Web Tarayıcı anahtar kavramı altı farklı (Yandex, Google, Mozilla Firefox, İnternet Explorer, Opera, Google Chrome,) cevap kelimeleri ile en çok kullanılan anahtar kavram olmuştur. Öğrencilerin Online Oyun anahtar kavramıla "Metin 2" cevap kelimesini ilişkilendirdikleri görülmektedir.

Köprü/Bağlantı (Link) ve Arama Motoru anahtar kavramı için “Facebook” cevap kelimesi bu kesme noktaları aralarında öğrenciler tarafından tercih edilmiştir. "YouTube" bir arama motoru olmamasına rağmen bu kesme aralığında öğrenciler tarafından Arama Motoru anahtar kavramıyla ilişkilendirilmiştir. Upload-Download anahtar kavramı için ön testte "İndirmek", "Müzik", "Film” ve “Oyun” cevap kelimeleri seçilmiştir. Online Eğitim anahtar kavramı için ön test sonuçlarında öğrenciler tarafından "Vitamin" ve "Eba" cevap kelimeleri kullanılırken, Lisanlı Yazılım anahtar kavramı için ise "Windows” cevap kelimesi kullanılmıştır. Öğrencilerin Online Alışveriş anahtar kavramına ilişkin ön test cevaplarında bu kesme aralığı için "Gittigidiyor" ve "Markofoni" cevap kelimeleri öğrenciler tarafından ifade edilmiştir. Yine bu kesme noktaları arasında So syal Ağlar anahtar kavramına ise öğrenciler tarafından “Ask.fm” cevabı ile yanıt verilmiştir.

Son kavram ăg haritaları

Aşağıdaki Şekil 8'de kelime ilişkilendirme ön testindeki anahtar kavramlara verilen cevap sayılarının 100200 arasında kesme noktasına göre hazırlanmış son kavram ağı haritaları verilmektedir. 


\section{Şekil 8.}

Kesme noktası 100-200'e göre oluşturulmuş son kavram ağı haritası

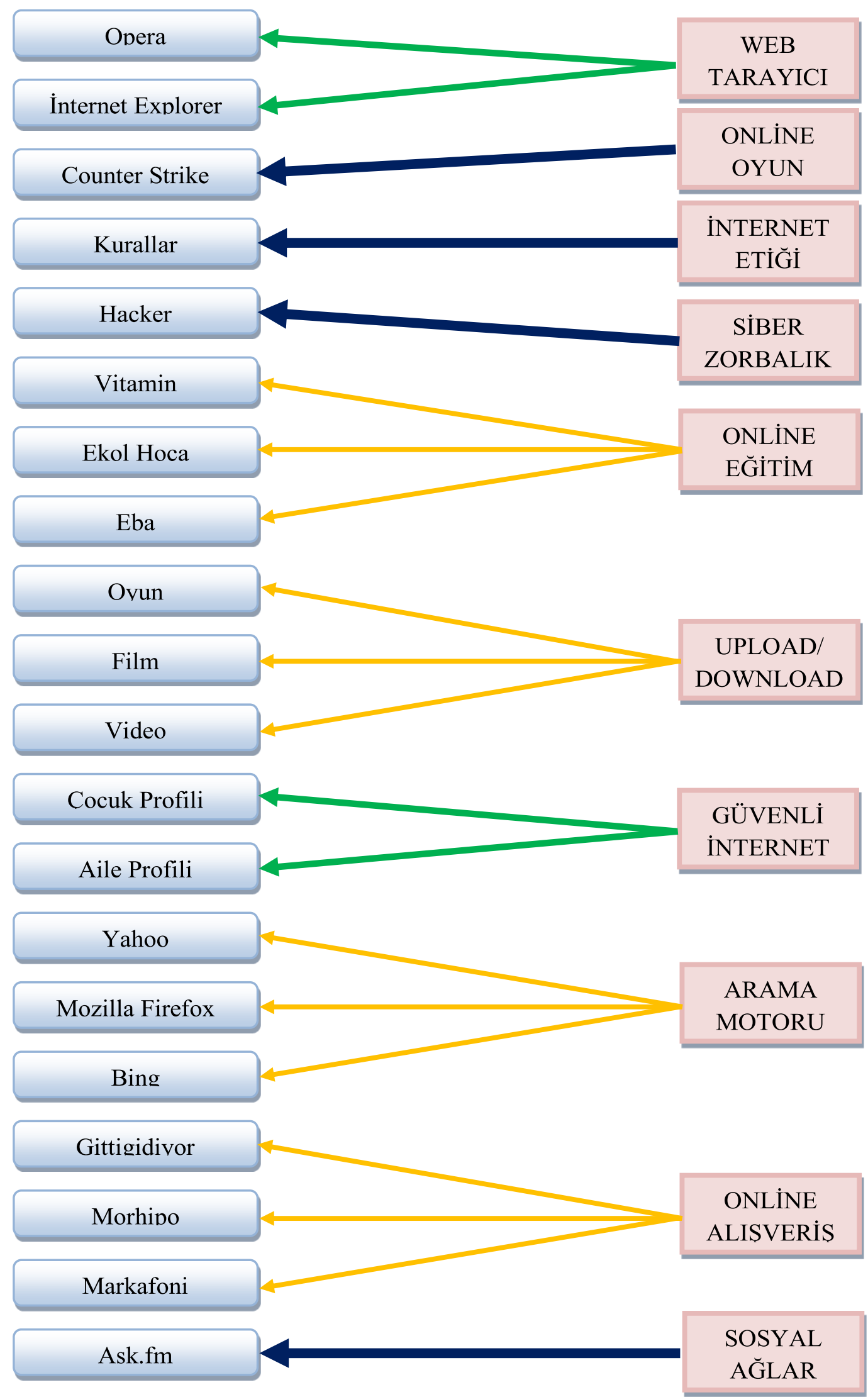


Kesme noktası 100-200 aralığında elde edilen son kavram ağları sonuçlarına göre, Web Tarayıcı anahtar kavramına "Opera" ve "İnternet Explorer" cevap kelimeleri ile yanit verilirken, Online Oyun anahtar kavramına ise "Counter Strike" cevap kelimesi ile yanıt verilmiştir. Aynı kesme noktası aralığındaki cevaplara göre, ön test sonuçlarında İnternet Etiği anahtar kavramı bu kesme noktaları arasında yer almazken, son test sonuçlarında bu anahtar kavramı "Kurallar" cevabı ile yer almaktadır. Siber Zorbalık anahtar kavramı ön test sonuçlarında öğrenci cevapları arasında bulunmamasına rağmen son test sonuçlarında öğrenciler "Hacker" cevap kelimesi ile Siber Zorbalık anahtar kavramına yanıt vermişlerdir.

Son test sonuçlarında bu kesme noktaları aralığında Online Eğitim anahtar kavramına "Vitamin", "Ekol Hoca" ve "Eba" cevapları verilmiştir. Bu anahtar kavrama ön testte "Vitamin" ve "Eba" cevapları verilirken, son test sonuçlarında "Ekol Hoca" seçeneği de eklenmiştir. Yine bu kesme noktaları arasında Upload-Download anahtar kavramı son test sonuçlarında "Oyun, "Film" ve "Video" kelimeleri ile cevaplanmıştır. Bu anahtar kavrama ön test sonuçlarındaki "Oyun" ve "Film” cevap kelimeleri ile ortak cevap verilmişken, "İndirmek” ve "Müzik" cevapları yerine "Video" kelimesi cevap olarak verilmiştir.

Güvenli İnternet anahtar kavramı son test sonuçlarında "Aile Profili" ve "Çocuk Profili" kelimeleri ile ifade edilmiştir. Öğrenciler ön test aşamasında bu anahtar kavrama çok farklı cevaplar verirken son test aşamasında Güvenli İnternet anahtar kavramını "Çocuk Profili” ve "Aile Profili” ile ilişkilendirmeyi tercih etmişlerdir. Arama Motoru anahtar kavramına ön testte arama motoru olmayan "Facebook" ve "YouTube" cevabi veren öğrenciler, son test sonucunda arama motoru olarak kullanılan "Yahoo" ve "Bing" kelimeleri ile cevap vermelerinin yanında yine bir arama motoru olmayan "Mozilla Firefox" kelimesi ile cevap vermişlerdir.

$\mathrm{Bu}$ kesme noktaları arasında Online Alışveriş anahtar kavramına verilen cevaplar açısından ön test ve son test sonuçları benzerlikler göstermektedir. Her iki testte de "Gittigidiyor" ve "Markafoni” cevapları ortak olarak verilmiştir. Son test sonuçlarında ise "Morhipo" cevabı da bu siteler arasında yer almıştır. Sosyal Ağlar anahtar kavramına ise hem ön testte hem de son testte "Ask.fm" cevabı verilmiştir.

\section{Kesme noktası 50-100 arası olan cevap kelimelerden oluşturulan kavram ağı haritaları}

Kelime ilişkilendirme testinin lise öğrencilerine ön test ve son test olarak uygulanması sonucunda oluşturulan frekans tablosuna göre belirlenen ve kesme noktası 50-100 arası olan cevap kelimelerden oluşturulan ön kavram ağı haritaları ve son kavram ağı haritaları aşă̆ıda verilmiştir.

\section{Ön kavram ăg haritaları}

Aşağıdaki Şekil 9' da kelime ilişkilendirme ön testindeki anahtar kavramlara verilen cevap sayılarının 50-100 arasında kesme noktasına göre hazırlanmış ön kavram ağı haritaları verilmektedir. 


\section{Şekil 9.}

Kesme noktası 50-100'e göre oluşturulmuş ön kavram ă̆l haritası

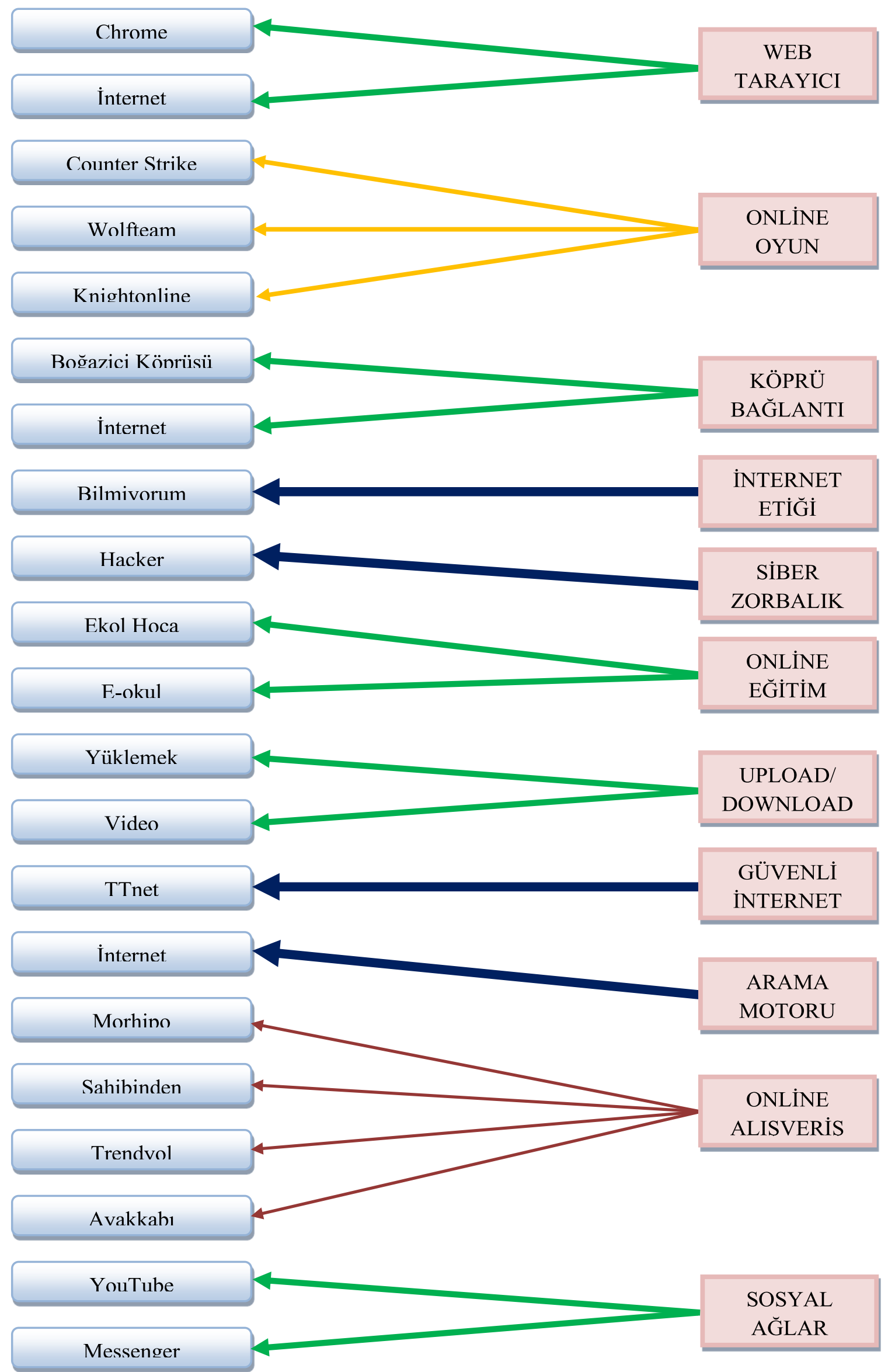


Kesme noktası 50-100 aralığında elde edilen ön test sonuçlarına göre, Web Tarayıcı anahtar kavramına "Chrome" ve "İnternet" cevapları verilirken, Online Oyun anahtar kavramına "Counter Strike", "Wolfteam" ve "Knightonline" cevaplarının verildiği görülmektedir. Yine bu kesme noktası aralığında ön testte öğrenciler Köprü/Bağlantı (Link) anahtar kavramına "Boğaziçi Köprüsü” ve "İnternet” cevaplarını verirlerken İnternet Etiği anahtar kavramına da "Bilmiyorum" cevabını vermişleridir.

Kesme noktası 50-100 aralığındaki ön test sonuçlarında Siber Zorbalık anahtar kavramına öğrenciler tarafından "Hacker" cevap kelimesi ile karşılık verdiği görülmektedir. Yine bu kesme noktası aralığında ön testte öğrenciler Online Eğitim anahtar kavramına "Ekol Hoca" ve "E-okul" cevap kelimeleri yanıtlar vermişlerdir. Upload-Download anahtar kavramı ön test sonuçlarında öğrenciler "Yüklemek" ve "Video" cevap kelimeleri ile algılarını ifade etmiştir. Bu kesme aralığındaki ön testte öğrenciler Güvenli İnternet anahtar kavramına "TTnet" kelimesi ile cevap verirken, Arama Motoru anahtar kavramına ise "İnternet" kelimesini kullanarak yanıt vermişlerdir. Ön test sonuçlarına göre Online Alışveriş anahtar kavramına öğrencilerden "Morhipo", "Sahibinden”, "Trendyol” ve "Ayakkabı" cevap kelimeleri ile yanıtlar alınmıştır. Ön test sonuçlarında son anahtar kavram olarak Sosyal Ağlar anahtar kavramı öğrenciler tarafından "YouTube" ve "Messenger" cevapları ile ifade edilmiştir.

Son kavram ăğ haritaları

Aşağıdaki Şekil 10'da kelime ilişkilendirme ön testindeki anahtar kavramlara verilen cevap sayılarının 50100 arasında kesme noktasına göre hazırlanmış son kavram ağı haritaları verilmektedir. 


\section{Şekil 10.}

Kesme noktası 50-100'e göre oluşturulmuş son kavram ă̆ haritası
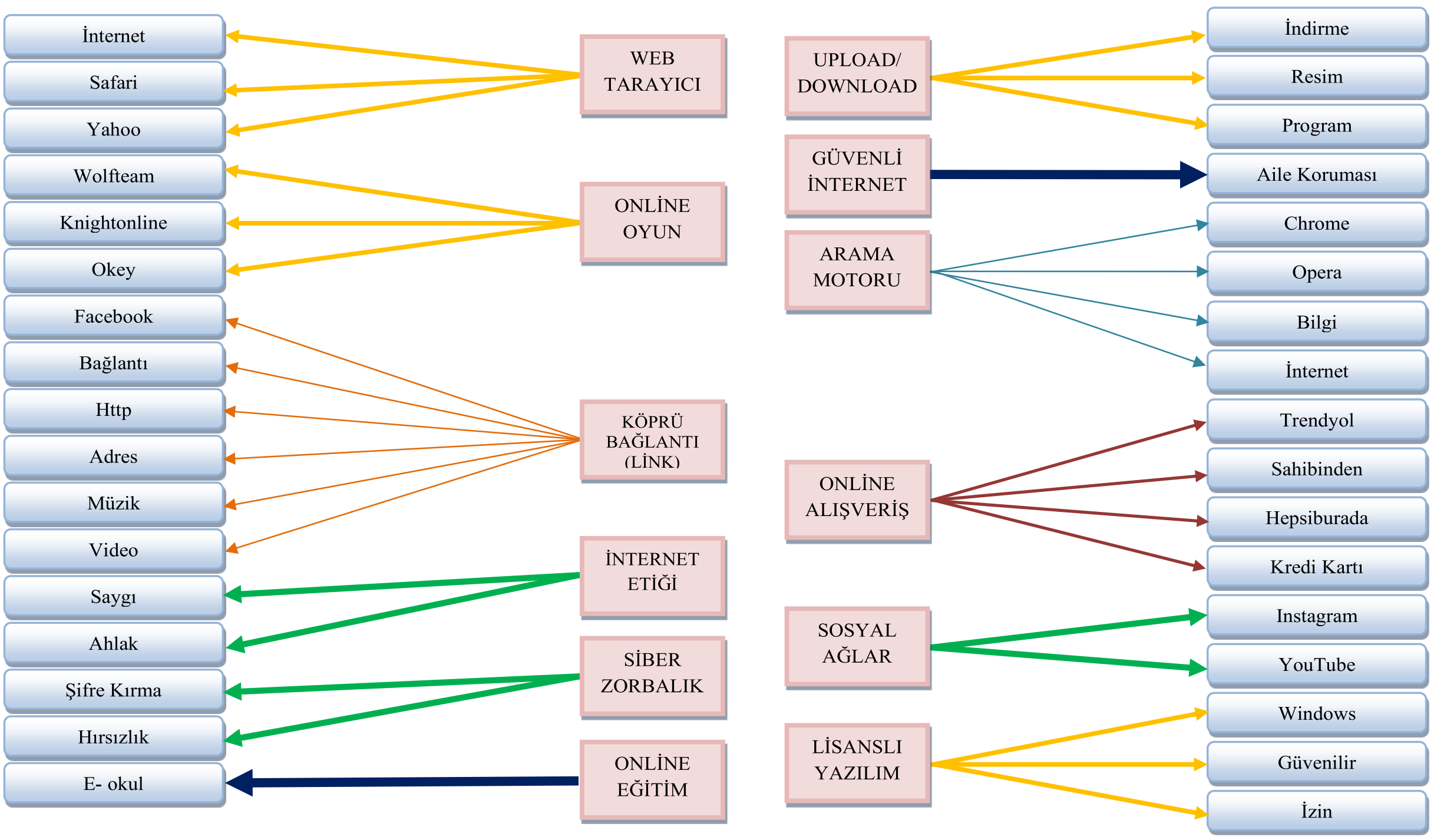
Ön test sonrası anahtar kavramlara ilişkin olarak öğrencilere verilen "İnternet Ka vramları Semineri” eğitimi sonrasında kesme noktası 50-100 aralığındaki son test sonuçlarında Web Tarayıcı anahtar kavramına öğrenciler tarafından "İnternet", "Safari" ve "Yahoo" cevap kelimeleri ile yanttlar verilirken Online Oyun kavramına "Wolfteam", "Knightonline" ve "Okey" cevap kelimelerinin verildiği görülmektedir. Yine bu kesme aralığında öğrencilerin Köprü/Bağlantı anahtar kavramına "Facebook", "Bağlantı", "Http”, “Adres”, "Müzik" ve "Video" cevaplarını verdikleri görülmektedir.

Kesme noktası 50-100 aralığına göre çizilen son kavram ağı haritasına göre, İnternet Etiği anahtar kavramına öğrenciler tarafından "Saygı" ve "Ahlak" cevap kelimeleri ile cevaplar verilirken Siber Zorbalık anahtar kavramına "Şifre Kırma" ve "Hırsızlık" cevaplarının verildiği görülmektedir. Yine bu kesme aralığında Online Eğitim anahtar kavramına öğrenciler tarafından sadece "E-okul” cevap kelimesi ile karşılık verilmiştir. Upload-Download anahtar kavramı için bu kesme aralığında öğrenciler tarafından verilen cevap kelimelere baktığımızda öğrencilerin "İndirme", "Program” ve "Resim” cevap kelimelerini tercih ettikleri görülmektedir.

Kesme noktası 50-100'e göre oluşturulmuş son kavram ağı haritasına göre Güvenli İnternet anahtar kavramına öğrenciler tarafından "Aile Koruması" cevap kelimesi ile yanıt verilirken Arama Motoru anahtar kavramına "Chrome”, "Opera”, "Bilgi” ve "İnternet" cevap kelimeleri ile yanıtların verildiği görülmektedir. Yine bu kesme noktasına göre çizilen son kavram ağı haritasına göre öğrencilerin Online Alışveriş anahtar kavramına “Trendyol”, "Sahibinden”, "Hepsiburada” ve Kredi Kartı” cevap kelimeleri ile yanıtlar verdiği görülmektedir.

Kesme noktası 50-100'e göre oluşturulmuş son kavram ağı haritasında bir diğer anahtar kavram olan Sosyal Ağlar kavramı öğrenciler tarafından "Instagram" ve "YouTube" cevap kelimeleri ile ifade edilmiştir. Yine bu kesme noktasına göre oluşturulan son kavram ağı haritasında öğrenciler Lisanslı Yazılım anahtar kavramını "Windows", "Güvenilir" ve "İzin” cevap kelimeleri ile yanıtlanmıştır.

\section{TARTIŞMA / SONUÇ / ÖNERİ}

\section{Öğrencilerin Cevap Kelime Sayılarına İlişkin Tartışma ve Sonuç}

Öğrencilerin ürettikleri cevap kelime sayısı açısından kelime ilişkilendirme ön test ve son test sonuçlarını incelediğimizde, kelime ilişkilendirme son testine göre kelime ilişkilendirme ön testinde daha fazla cevap kelime ürettikleri sonucuna ulaşmıştık. Bu durum öğrencilerin “İnternet Kavramı Semineri”ni aldıktan sonra kendilerine sunulan kavramlarla ilgili bilişsel yapılarındaki yanlış olan kelimeleri eleyerek kelime ilişkilendirme son testinde söylememiş olmalarıyla açıklanabilir. Ancak, öğrenciler tarafından üretilen kelime sayısının fazla olması kavram ile ilgili bilginin niteliği hakkında çok fazla geri bildirim sağlamayabilir. Kelime ilişkilendirme testinde önemli olan cevap kelimelerin niteliği ve kalitesidir. Cevap kelimelerin niteliği ve kalitesi ise, anlamlı, bilimsel, doğru ve kavram ile ilgili doğrudan bağlantılı olmasına bağlıdır. Cevap kelime sayısı ve çeşidi kavramı anlamayı tek başına açıklayamayacağı, verilen cevap kelimelerin niteliğinin de önemli olduğu birçok araştırmacı (Bahar ve ark., 1999; Shavelson, 1974; Yalvaç, 2008) tarafından da dile getirilmiştir.

\section{Öğrencilerin Cevap Kelime Çeşitlerine İlişsin Tartışma ve Sonuç}

Öğrencilerin ürettikleri cevap kelime çeşidi açısından kelime ilişkilendirme ön test ve son test sonuçlarını incelediğimizde, anahtar kavramlara verilen cevap çeşitlerine ilişkin sonuç ve tartışmalar aşağıda sırasıyla verilmiş̧ir.

Web Tarayıcısı anahtar kavramına öğrenciler tarafından ön testte 2213 adet cevap kelimesi ve 39 adet cevap çeşidi üretilmiş̧ir. Son testte ise öğrenciler tarafından 2219 adet cevap kelime üretilmiş ve 29 adet cevap çeşidi ile yanıt verilmiştir. Ön test ile son test sonuçları arasında hem cevap çeşidi hem de cevap sayısında azalma olduğu görülmektedir. Bu durum, öğrencilerin anahtar kavrama ilişkin bilinç düzeylerinin seminer eğitimi sonrasında artmış olması ile ilişkilendirilebilir. Örneğin, öğrenciler ön testte Web Tarayıcısı a nahtar kavramına Mozilla(164) cevap kelimesi ile yanıt verirken son test sonucunda bu yanıt öğrenciler tarafından 
Mozilla Firefox(252) olarak ifade edilmiştir. Sonuçlardan da görüleceği üzere öğrencilerin Web Tarayıcısı anahtar kavramı ile ilgili kavrama daha uygun kelimeler kullandıkları ve bu nedenle cevap çeşitlerinin azaldı ğ sonucu ortaya çıkmaktadır. Web tarayıcılarından daha sık kullanılanlarının tekrarlanma sayılarının arttığı görülmektedir.

Köprü/Bağlantı(Link) anahtar kavramına öğrenciler ön testte 2234 cevap kelimesi üretmiş ve 66 cevap çeşidi ile karşı1ık vermiştir. Aynı anahtar kavrama öğrenciler son testte 2215 cevap kelimesi ile karşılık vermiş ve 71 cevap çeşidi üretmiştir. Öğrencilerin anahtar kavrama ilişkin cevap çeşit sayılarının arttığı ancak toplam cevap sayılarının azaldığı görülmektedir. Öğrencilerin ön testte verdikleri Meyve Suyu(46), İçecek(41) ve İnternet(73) gibi cevapların son testte olmadığı, bunun yerine Bağlantı(74), Adres(57) ve http(57) gibi anahtar kavrama ilişkin daha uygun kelimeler kullandıkları görülmektedir. Ön test ve son test arasında verilmiş olan seminer eğitiminin öğrencilerin cevaplarını anahtar kavrama daha uygun olarak vermesinde faydalı olduğu ifade edilebilir. Öğrencilerin cevap kelime sayılarının azalması zihinlerindeki bu anahtar kavramla ilgili anlamsız cevapları eleyerek anahtar kavrama daha uygun cevaplar verdiklerini ortaya koymaktadır.

Arama Motoru anahtar kavramına ön testte öğrenciler 2249 cevap sayısı ile karşılık vermiş ve 36 cevap çeşidi üretmişlerdir. Öğrenciler son testte ise 2130 cevap kelimesi üretmiş ve 28 cevap çeşidi kullanmıştır. Bu sonuçlara göre öğrencilerin cevap kelime sayısı ve cevap çeşitleri ön teste göre son testte azalmıştır. Öğrencilerin aldıkları seminer eğitimi sonucunda bu anahtar kavramla ilgili anlamsız cevapları eleyerek anahtar kavrama daha uygun cevaplar verdiklerini ifade etmek mümkündür. Örneğin ön testte Facebook(114) arama motoru olarak ifade edilirken, seminer eğitimi sonrasında öğrenciler Facebook kelimesini arama motoru cevabı olarak belirtmemişlerdir. Bunun yanında öğrenciler anahtar kavrama ön testte en çok Google(361) cevap kelimesini üretirlerken son testte de Google(373) cevap kelimesi frekansı artarak yine öğrenciler tarafından en çok üretilen cevap kelime olduğu görülmektedir. Yani son testte bu anahtar kavram için öğrenciler tarafından üretilen cevap çeşit sayısının azalırken cevap kelime frekansının artması öğrencilere verilen “İnternet Kavramları Semineri”nin öğrencilerin bilişsel yapılarının gelişmesinde etkili olduğunu sonucunu göstermektedir. Kurulgan ve Argan (2007) üniversite öğrencilerinin internette bilgi arama davranışları üzerinde yapılmış ve araştırma sonuçlarında Google öğrenciler arasında en yüksek oranda, Yahoo ise ikinci sırada tercih edilen arama motorları olarak belirtilmiştir. Bizim çalışmamızda ise son test sonuçlarına göre Arama Motoru kavramına öğrenciler tarafından en çok Google(373) ikinci sırada ise Yandex(347) cevap kelimesi yanıt olarak verilmiştir. Benzer bir çalışmada Çelen ve Seferoğlu (2017) öğrencilerin internette bilgi arama biçimlerini araştırmışlar ve öğrencilerin herhangi bir konuda arama ve araştırma yaparken arama motorlarından en çok Google arama motorunu kullandıkları sonucuna ulaşmışlardır. Sonuç olarak bu çalışmada da hem ön teste hem de son testte Arama Moturu anahtar kavramına öğrenciler tarafından en çok Google cevap kelimesi verilmiştir. Bu da benzer araştırmalarda bulunan sonuçlarla örtüşmektedir.

Upload-Download anahtar kavramına öğrenciler tarafından ön testte 2228 adet cevap kelimesi üretilmiş ve 34 adet cevap çeşidi ile yanıtlar verilmiştir. Öğrenciler bu anahtar kavram için son testte ise 2123 adet cevap kelime üretmiş ve bu kelimelerden 51 adet cevap çeşidi belirlenmiştir. Bu sonuçlara göre, son testte cevap kelime sayısı azalırken, cevap çeşitleri ise artmıştır. Ön testte İndirme(177), Müzik(168), Film(142), Oyun(110) ve Yüklemek(85) cevap çeşitleri ile yanıtlar verilmişken, seminer eğitimi sonrasında Müzikmp3(214) ile birinci sırada ifade edilen cevap kelime olmuştur. Son testte Yüklemek(205) cevap kelimesinin frekansı artış gösterirken, İndirmek(152) ve Film(121) cevap kelimelerinin frekansları ön teste göre azalış göstermiştir. Bu anahtar kavrama yönelik olarak öğrencilerin cevap kelime çeşitleri artmış olsa da, anahtar kavrama ilişkin verdikleri cevap kelime sayıları azalmıştır. Öğrencilerin benzer cevap kelimeleri hem ön testte hem de son testte kullandıkları görülmektedir.

Online Eğitim anahtar kavramına öğrenciler ön testte 2221 cevap sayısı ve 57 cevap çeşidi ile yanıtlar vermiştir. Son testte 2105 cevap sayısı ve 70 cevap çeşidi tespit edilmiştir. Son testte anahtar kavrama ilişkin cevap çeşidi sayısının artmasına rağmen toplam cevap sayısında azalma görülmektedir. Vitamin(168), Ekol Hoca(128), Eba(103) ve E-okul(55) gibi cevap kelimeler son testte cevap sayıs olarak daha fazla 
tekrarlanmıştır. Öğrencilerin internet ortamında online eğitim konusunda Mili Eğitim Bakanlığına ait siteleri kullandıkları diğer araştırmacıların çalışmalarında da belirtilmektedir. Örneğin bu çalışmalardan birinde Ekici ve Uçak (2012) tarafından ilköğretim öğrencileri üzerine yapılmış olan araştırmada, öğrencilerin Milli Eğitim Bakanlığına bağlı siteleri yoğun olarak kullandıkları sonucuna ulaşılmıştır.

Online Alışveriş anahtar kavramına öğrenciler ön testte 2233 adet cevap kelimesi ve 44 adet cevap çeşidi üretirken son testte bu anahtar kavrama öğrenciler tarafından 2138 adet cevap kelimesi ve 49 adet cevap çeşidi üretilmiştir. Buna göre öğrencilerin anahtar kavrama ilişkin cevap çeşit sayılarının arttığı ancak toplam cevap sayılarının azaldığı söylenebilir. Öğrenciler ön testte Online Alışveriş anahtar kavramına en çok Gittigidiyor(155) cevap kelimesi ile yanıt verirken, seminer eğitimi sonrasında da yine Gittigidiyor(158) cevap kelimesi ile yanıt vermişlerdir. Yani öğrencilerin benzer cevap kelimeleri hem ön testte hem de son testte kullandıkları söylenebilir. Silkü (2009)'nün üniversite öğrencilerinin internetten alışverişe yönelik tutumlarını araştırdığg bir çalışmanın sonucunda üniversite öğrencilerinin online alışveriş için en çok kullandığı mağazanın Gittigidiyor olduğu ortaya çıkmıştır.

Sosyal Ağlar anahtar kavramına öğrenciler ön testte 2233 cevap sayısı ile karşı1ık vermiş ve 32 cevap çeşidi kullanmıştır. Son testte ise bu anahtar kavram için öğrenciler 2121 cevap sayısı ve 30 cevap çeşidi üretmişlerdir. Bu sonuçlara göre, öğrencilerin ön testte daha fazla cevap sayıs1 ve cevap çeşidi kullandığ sonucu ortaya çıkmaktadır. Öğrenciler ön testte Online Alışveriş anahtar kavramına en çok Facebook(392) ve Twitter(358) cevap kelimeleri ile yanıt verirken, seminer eğitimi sonrasında da yine Facebook(407) ve Twitter(378) cevap kelimesi ile yanıt vermişlerdir. Sonuç olarak, öğrencilerin benzer cevap kelimeleri hem ön testte hem de son testte kullandıkları söylenebilir. Ancak, bu anahtar kavram için son testte bu öğrenciler tarafından üretilen cevap çeşit sayısının azalırken cevap kelime frekansının artması öğrencilere verilen “İnternet Kavramları Semineri”nin öğrencilerin bilişsel yapılarının gelişmesinde etkili olduğunu sonucunu göstermektedir. Koç ve Tatlı (2017) tarafından üniversite öğrencilerinin sosyal ağlar ile ilgili tutumlarına yönelik olarak yapılan araştırma sonucunda da Facebook ve Twitter öğrenciler arasında en çok kullanılan sosyal ağ sitesi olarak bulunmuştur. Yine benzer bir çalışmada Yıldız ve Abdüsselam (2016) ise ortaokul ve ortaöğretim öğrencilerinin internet kullanımına yönelik olarak yaptıkları araştırmada öğrencilerin en çok kullandıkları sosyal ağ sitesinin sırasıyla Facebook, Instagram ve Twitter olduğu sonucuna ulaşmışlardır.

Online Oyun anahtar kavramına ön testte öğrenciler tarafından 2240 adet cevap kelimesi ve 48 adet cevap çeşidi ile yanıtlar verilirken son testte bu kavrama 2132 adet cevap kelimesi ve 64 adet cevap çeşidi kullanılmıştır. Bu sonuçlara göre ön testte öğrencilerin daha fazla cevap sayısı ile Online Oyun anahtar kavramına yanıtlar verdiği ancak son testte daha fazla cevap çeşidi kullandığ görülmektedir. Bu sonuçlara göre, öğrencilerin son testte cevap kelime sayısı azalırken, cevap çeşitlerinin ise arttığı söylenebilir. Ön testte öğrenciler bu anahtar kavrama Metin 2(189), Counter Strike(83) ve Wolfteam(71) cevap çeşitleri ile yanıtlar verirlerken, seminer eğitimi sonrasında da yine Metin 2(296), Counter Strike(140) ve Wolfteam(89) cevap çeşitlerini kullanmışladır. Sonuç olarak öğrencilerin benzer cevap kelimeleri hem ön testte hem de son testte kullandıkları görülmektedir.

Güvenli İnternet anahtar kavramına öğrenciler ön testte 2220 cevap sayısı ile karşılık vermiş ve 16 cevap çeşidi kullanmıştır. Son testte ise öğrenciler bu anahtar kavrama 2117 cevap sayısı ve 53 cevap çeşidi ile karş11ık vermişlerdir. Buna göre, öğrencilerin Güvenli İnternet anahtar kavrama ilişkin cevap çeşidinin arttığ ancak toplam cevap sayılarının azaldığı görülmektedir. Öğrencilerin ön testte bu anahtar kavrama TTnet(85), Kısıtlama(33) ve Yasak Siteler(33) gibi cevap çeşitleri ile karş1lık verdikleri görülmektedir. Öğrencilerin ön test sonrasında almış oldukları "İnternet Kavramları Semineri” eğitim neticesinde son test cevaplarında ise Çocuk Profili(134), Aile Profili(128) ve Aile Koruması(52) cevaplarını verdikleri belirlenmiştir. Bu cevaplara göre, öğrencilerin seminer eğitimi sonrasında anahtar kavrama yönelik olarak daha uygun cevap kelimler ile yanıtlar verdikleri, öğrencilerin almış oldukları seminer eğitiminin bilgi düzeylerinde olumlu yönde farklılık yarattığı ve bunun sonucunda da anahtara kavrama yönelik olarak daha uygun kelime çeşitlerini tercih ettiklerini söyleyebiliriz. Çelen ve ark. (2011) ebeveynlerin çocukların ve gençlerin çevrimiçi ortamlarda 
karşılaşabilecekleri istenmeyen durumlar açısından güvenliği sağlama konusunda öncelikli sorumlu olduğunu ifade ederken, Demirel ve ark. (2013) yaptıkları bir çalışmada ebeveynlerin sadece \%36,9'unun internet filtresi kullandığını ve internet filtresi kullananların da \%87,1'isinin “Aile Profili”, \%12.9'unun ise “Çocuk Profili” kullandığını belirlemişlerdir.

Siber Zorbalık anahtar kavramına öğrenciler tarafindan ön testte 2223 adet cevap kelimesi ve 61 adet cevap çeşidi üretilmiştir. Son testte ise öğrenciler tarafından 2113 adet cevap kelime üretilmiş ve 60 adet cevap çeşidi ile yanıt verilmiştir. Bu sonuca göre, Siber Zorbalık anahtar kavramı için öğrencilerin ön test ve son testte ürettikleri cevap kelime çeşidi açısından çok önemli bir değişim olmadığı söylenebilir. Son testte öğrencilerin cevap sayısı azalırken, cevap çeşidi hemen hemen aynı kalmıştır. Öğrenciler kelime çeşidi bakımından ön testte Kavga(29), İnternet(28) ve Bilmiyorum(25) gibi cevap kelimeler üretirken, son testte Hacker(114), Şifre Kırma(71), Hırsılık(51), Tehdit(34) ve Zorbalık(31) gibi Siber Zorbalık anahtar kavramı ile ilgili daha uygun cevap kelimeler üretmişlerdir. Sonuç olarak öğrencilerin ön testten sonra aldıkları “İnternet Kavramları Semineri” eğitiminin Siber Zorbalık anahtar kavramına yönelik bilişsel yapılarının gelişmesinde etkili olduğunu söyleyebiliriz.

İnternet Etiği anahtar kavramına öğrenciler ön testte 2215 cevap sayısı ile karşılık vermiş ve 49 cevap çeşidi kullanmıştır. Son test sonuçlarında ise öğrenciler aynı anahtar kavrama 2096 cevap sayısı ile karşılık vermiş ve 71 cevap çeşidi kullanmışlardır. Bu sonuçlar, öğrencilerin İnternet Etiği anahtar kavramı için bilgi düzeylerinin geliştiği ve bunun neticesinde de son testte ön teste göre daha fazla cevap çeşidi ürettiği şeklinde yorumlanabilir. Nitekim öğrenciler ön testte İnternet Etiği anahtar kavramı için Bilmiyorum(71), İnternet(23), Et(23) ve Etek(23) gibi cevap kelimeler kullanırken, son testte Kurallar(103), Sayg1(61) ve Ahlak(60) gibi bu anahtar kavrama daha uygun cevap kelimeler kullanmışladır.

Lisanslı Yazılım anahtar kavramına öğrenciler tarafından ön testte 2224 adet cevap kelimesi ve 68 adet cevap çeşidi üretilmiştir. Son testte ise öğrenciler tarafından 2118 adet cevap kelime üretilmiş ve 68 adet cevap çeşidi ile yanıt verilmiştir. Bu sonuca göre, Lisanslı Yazılım anahtar kavramı için öğrencilerin ön test ve son testte ürettikleri cevap kelime çeşidi aynı kalırken, ön testte ürettikleri cevap kelime sayısı son teste göre azalmıştır. Öğrenciler kelime çeşidi bakımından ön testte Windows(102), Microsoft Office(46) ve Program(35) gibi cevap kelimeler üretirken, son testte Güvenilir(62), İzin(55) ve Orijinal(32) gibi Lisansl1 Yazılım anahtar kavramı ile ilgili daha uygun cevap kelimeler üretmişlerdir. Sonuç olarak öğrencilerin ön testten sonra aldıkları “İnternet Kavramları Semineri” eğitiminin Lisanslı Yazılım kavramına yönelik bilişsel yapılarının gelişmesinde etkili olduğunu söyleyebiliriz.

\section{Öğrencilerin Ön ve Son Kavram Ağı Haritalarına İliş̧kin Tartışma ve Sonuç}

Kelime ilişkilendirme testi sonuçlarının analizinde sadece anahtar kavramlara verilen cevap kelime çeşitleri kullanılmaz, aynı zamanda anahtar kavramlara verilen ortak cevap kelimelerin sayısı ve bunların söylenme sırası da önemlidir (Eren, 2012). Bu da anahtar kelimeler arasındaki anlamsal yakınlı̆̆ın analiz edilmesini ve bunu haritalamamızı sağlar (Bahar ve Özatl1, 2003). Bunun için öğrencilerin anahtar kavramlara verdiği cevap kelimelerden faydalanılarak kavram ağları oluşturulmuş ve kavramlar arası ilişkilere bakılmıştır. Araştırmada kelime ilişkilendirme testinin çalışma grubu öğrencilerine ön test ve son test olarak uygulanması sonucunda öğrencilerin anahtar kavramlar ile ilgili olarak verdikleri cevap kelimelerin sayıları için kesme noktası tekniğine göre çizilen ön kavram ağı haritaları ile son kavram ağı haritaları karşılaştırılmış ve bu karşılaştırma ile ilgili sonuç ve tartışma aşağıda sunulmuştur.

Kesme noktası 400 ve üzerine göre oluşturulan kavram ağında kavramlar arası en güçlü ilişkiler ortaya çıkmıştır. Araştırmada ön test sonuçlarına göre kesme noktası 400 ve üzeri cevap kelimelerine karşı1ık sonuçlar elde edilemediği için ön kavram ağı haritaları oluşturulamamıştır. Son test sonuçlarına göre ise, öğrenciler Sosyal Ağlar anahtar kavramına "Facebook" cevap kelimesi ile yanıt vermişlerdir. Sonuç olarak, ön test sonrası öğrencilere verilen "İnternet Kavramları Semineri” eğitimi neticesinde "Facebook" cevap kelimesinde artış olduğu söylenebilir. 
Kesme noktası 300-400 arası olan cevap kelimelerden oluşturulan ön kavram ağı sonuçlarına göre, Sosyal Ağlar anahtar kavramına "Facebook" ve "Twitter" cevap kelimelerini kullandıkları görülmektedir. Ön test aşamasındaki "Facebook" cevap kelimesinde son testte artış olmuş ve algılarda farklılıklar ortaya çıkmıştır. Aynı zamanda bu kesme noktaları arasında ön test sonucuna göre Arama Motoru anahtar kavramına öğrencilerin "Google" cevap kelimesini kullandıkları tespit edilmiştir. Öğrencilere anahtar kavramlarla ile ilgili olarak verilen "İnternet Kavramları Semineri” neticesinde son testte bu kesme noktası aralı̆̆ında Sosyal Ağlar anahtar kavramına "Twitter" cevap kelimesini kullanarak cevap verildiği düşünülmektedir. Yine bu kesme noktası aralığındaki son test sonuçlarına göre Arama Motoru anahtar kavramına öğrencilerin "Google" cevap kelimesi ile birlikte "Yandex" cevap kelimesini kullandıkları görülmektedir. Bu durumda, ön test ve son test sonuçları arasındaki farklılığı, öğrencilerinin bilgi düzeylerinin arttıkça anahtar kavramlara ilişkin verdikleri cevapların daha uygun ifadelerle cevapladıkları şeklinde yorumlamak doğru olacaktır.

Kesme noktası 200-300 arası olan cevap kelimelerden oluşturulan ön kavram ağı sonuçlarına göre, Arama Motoru anahtar kavramına "Yandex" kelimesi ile cevap verilmiştir. Bu sonuca göre öğrencilerin eğitim almadan önce ön test aşamasında Arama Motoru Anahtar kavramına Google'dan sonra en çok Yandex'i kullandıkları söylenebilir. Yine bu kesme noktası aralığında elde edilen ön test sonuçlarına göre ise öğrencilerin Online Oyun anahtar kavramına "Metin 2" cevap kelimesini, Upload/Download anahtar kavramına "İndirmek", "Müzik (mp3)" ve "Yüklemek" cevap kelimelerini; Web Tarayıcısı anahtar kavramına Mozilla Firefox", "Google", "Yandex" ve "Chrome" cevap kelimelerini verdikleri görülmektedir. Öğrencilerin ön test sonrasında aldıkları "İnternet Kavramları Semineri” eğitimi neticesinde son testte anahtar kavramlara daha uygun cevaplar verdikleri söylenebilir. Bu kesme noktası aralığında elde edilen son kavram ağı sonuçlarına göre öğrencilerin ön teste verdikleri cevapları ile eğitim sonrası son teste verilen cevaplar arasında farklılıklar ortaya çıkmıştır. Ön testte öğrenciler sadece Arama Motoru anahtar kavramına tek bir cevap ile karşılık vermişken, son teste Online Oyun, Upload-Download ve Web Tarayıcı anahtar kavramlarına sekiz farklı cevap ile karşılık vermişlerdir. Bu sonuçlara göre öğrencilerin aldıkları "İnternet Kavramları Semineri" sonunda belirlenen anahtar kelimeleri algıladıkları ve daha uygun cevaplar verdikleri söylenebilir. Özellikle seminer eğitimi sonrası öğrencilerin cevaplarında görülen bu değişimler, bazı anahtar kavramlara ilişkin kulaktan dolma bilgilere sahip olduklarını ve net bilgilerinin olmadığını göstermektedir. Ancak anahtar kavramlarla ilgili olarak öğrencilere verilen "İnternet Kavramları Semineri” eğitimi sonrasında yapılan son testte öğrencilerin anahtar kavramlara çok daha uygun cevaplar verdikleri belirlenmiştir.

Kesme noktası 100-200 arası olan cevap kelimelerden oluşturulan ön kavram ağı sonuçlarına göre, Web Tarayıcı, Online Oyun, Köprü/Bağlantı (Link), Arama Motoru, Upload-Download, Online Eğitim, Lisanslı Yazılım, Online Alışveriş ve Sosyal Ağlar anahtar kavramları ortaya çıkmış ve sonuç olarak dokuz farklı anahtar kavram öğrenciler tarafından ifade edilmiştir. Bu anahtar kavramlar 20 farklı cevap kelimesi ile ifade edilirken, Web Tarayıcı anahtar kavramı altı farklı (Yandex, Google, Mozilla Firefox, İnternet Explorer, Opera, Google Chrome,) cevap kelimeleri ile en çok kullanılan anahtar kavram olmuştur. Öğrencilerin Web Tarayıcılar için aklına gelen ilk kelimeyi günlük hayatta yaygın olarak kullandıkları web tarayıcılarıyla ilişkilendirdikleri söylenebilir.

Öğrencilerin Online Oyun anahtar kavramıyla "Metin 2" cevap kelimesini ilişkilendirdikleri görülmektedir. Özellikle medya tarafından gündemde tutulan ve bu yaş grubunda favori olarak oynanan oyunların başında gelen "Metin 2" oyununun akla gelen ilk oyunlardan olduğu düşünülmektedir. "Facebook" günümüzde en çok kullanılan sosyal iletişim araçlarından biridir. Bu bağlamda Köprü/Bağlantı (Link) ve Arama Motoru anahtar kavramlarında "Facebook" cevap kelimesi bu kesme noktaları arasında öğrenciler tarafından tercih edildiği söylenebilir. "YouTube" bir arama motoru olmamasına rağmen bu kesme aralığında öğrenciler tarafından Arama Motoru anahtar kavramıyla ilişkilendirilmiştir. "YouTube"da öğrencilerin keyifli vakit geçirmelerini sağlayan müzik, oyun, film, ders ve çeşitli alanlarda birçok videoya erişim imkanının olmasının "YouTube"un cevap kelime olarak tercih edilmesinde etkili olduğu düşünülmektedir.

Upload-Download anahtar kavramında ön test sonuçlarına göre "İndirmek", "Müzik", "Film” ve "Oyun" 
cevap kelimeleri seçilmiştir. Öğrencilerin günlük hayatlarında internette upload ve download işlemleri için en çok bu cevap kelimeleri kullandıkları sonucu ortaya çıkmaktadır. Yani öğrencilerin film, oyun ve müzik alanlarında upload veya download işlemleri gerçekleştirdikleri düşünülebilir. 100-200 kesme noktaları arasında Online Eğitim anahtar kavramı ön test sonuçlarında ise "Vitamin" ve "Eba" cevap seçenekleri kullanılmıştır. Web ortamında öğrencilerin ders çalışmak veya araştırma yapmak için bu siteleri tercih ettikleri sonucunu ifade etmek doğru olacaktır. Öğrenciler Lisanlı Yazılım anahtar kavramı ön test sonuçlarında "Windows" cevap kelimesini bu kesme noktaları arasında tercih etmiştir. Kişisel bilgisayarda yaygın olarak kullanılan bu programın öğrenci algılarında lisanslı olduğu sonucu ortaya çıkardığı söylenebilir.

Ön test sonuçlarında Online Alışveriş anahtar kavramına ilişkin olarak öğrenciler tarafından "Gittigidiyor” ve "Markofoni" cevap kelimeleri verilmiştir. Bu sonuca göre "Gittigidiyor" ve "Markofoni” cevap kelimelerinin öğrenci algılarında online alışveriş siteleri olduğu söylenebilir. Öğrenciler bu alışveriş sitelerini ya reklamlardan ya da ailelerinin alışveriş tercihlerinden öğrenmiş oldukları ve bunun için cevap olarak vermiş oldukları düşünülebilir. Yine bu kesme noktaları arasında Sosyal Ağlar anahtar kavramına ise öğrenciler tarafından “Ask.fm” cevabı ile yanıt verilmiştir. Bazı öğrencilerin günlük yaşamlarında "Ask.fm” sitesini sosyal bir iletişim aracı olarak gördükleri ve kullandıkları düşünülebilir. Öğrencilere ön test yapıldıktan sonra anahtar kavramlarla ilgili olarak "İnternet Kavramları Semineri” eğitimi verilerek son test aşamasında aynı anahtar kavramlar hakkında cevaplar alınmıştır. 100-200 aralığındaki kesme noktaları için öğrenciler Web Tarayıc1, Online Oyun, İnternet Etiği, Siber Zorbalık, Online Eğitim, Upload-Download, Güvenli İnternet, Arama Motoru, Online Alışveriş ve Sosyal Ağlar anahtar kavramlarına ilişkin cevap kelimeleri ile yanıtlar vermiştir. Bu kesme noktaları arasında son test sonuçlarına göre algılarda farklılıklar olduğu görülmektedir.

Kesme noktası 100-200 arası olan cevap kelimelerden oluşturulan son kavram ağı sonuçlarına göre, Web Tarayıcı anahtar kavramına "Opera" ve "İnternet Explorer" cevap kelimeleri ile yanıt verilmiştir. Ön test sonuçlarında 6 farklı cevap kelimesi ile bu anahtar kavrama cevap verilmişken, seminer eğitimi sonucunda öğrencilerin algılarında değişimlerin oluştuğu ve bunun sonucunda da "Opera” ve "İnternet Explorer" cevap kelimeleri ile yanıtların verildiği söylenebilir. Bu sonuca göre, öğrencilerin ön test ile son test arasında anahtar kavramlara ilişkin olarak verilen "İnternet Kavramları Semineri” eğitimi sayesinde anahtar kavramlara daha uygun cevap kelimeleri kullandıkları söylenebilir. Yine bu kesme aralığındaki son test sonuçlarında Online Oyun anahtar kavramına "Counter Strike" cevap kelimesi ile yanıt verilmiştir. Bu anahtar kavrama ön test aşamasında öğrenciler tarafından "Metin 2" cevap kelimesi ile cevap verilmişken, son testte "Metin 2" cevabının frekansı arttı̆̆ için son kavram haritasında yer almamıştır. Ancak, son testte öğrencilerin bu kesme aralığında "Counter Strike" cevabını verdikleri görülmektedir. Sonuç olarak burada, öğrencilerin günlük hayatlarında bazı oyun alışkanlıklarının ortak olduğu ve aynı tür oyunları yoğun olarak oynadıkları ifade edilebilir.

Aynı kesme noktası aralığındaki cevaplara göre, ön test sonuçlarında İnternet Etiği anahtar kavramı bu kesme noktaları arasında yer almazken, son test sonuçlarında bu anahtar kavramı "Kurallar" cevabı ile yer almaktadır. Bu sonuç, öğrencilere verilen seminer eğitiminin algılarında farklılık yarattığı ve internet etiği ile ilgili daha detaylı olarak düşündüklerini göstermektedir. Öğrencilerin internet kullanımlarında etiği kurallar ile ilişkilendirdikleri ve İnternet Etiği anahtar kavramı hakkında anlayışlarının farklılaştığı sonucunu ortaya çıkarmaktadır.

Siber Zorbalık anahtar kavramı 100-200 aralığındaki kesme noktası için ön test sonuçlarında öğrenci cevapları arasında bulunmamasına rağmen son test sonuçlarında öğrenciler "Hacker" cevap kelimesi ile Siber Zorbalık anahtar kavramına yanıt vermişlerdir. Öğrencilerin siber zorbalık konusunda verilen "İnternet Kavramları Semineri" eğitimi sayesinde bu kavram hakkında algılarında değişimlerin olduğu düşünülmektedir. Öğrenciler son test sonuçlarında bu kesme aralığında Online Eğitim anahtar kavramına "Vitamin", "Ekol Hoca" ve "Eba" cevapları verilmiştir. Ön test sonuçlarında "Vitamin" ve "Eba" cevapları verilirken, son test sonuçlarında "Ekol Hoca" seçeneği de eklenmiştir. Ön test ve son test sonuçlarında bu kesme noktaları arasında öğrenci algılarındaki bu benzerlikler öğrencilerin aynı siteler üzerinden ders çalıştıkları ya da 
araştırma yaptıkları şeklinde yorumlanabilir.

Bu kesme noktaları arasında Upload-Download anahtar kavramı son test sonuçlarında "Oyun, "Film" ve "Video" kelimeleri ile cevaplanmıştır. Bu anahtar kavram için ön testte "Oyun" ve "Film" cevap kelimeleri ile ortak cevap verilmişken, son testte "İndirmek" ve "Müzik" cevapları yerine "Video" kelimesi cevap olarak verilmiştir. Bu sonuç, öğrencilerin "İnternet Kavramları Semineri” eğitimi sonrası daha çok kullandıkları Download-Upload cevaplarını tercih ettikleri anlamını taşımaktadır. Özellikle film, oyun ve videolarla Upload-Download anahtar kavramını ilişkilendirdikleri sonucu ortaya çıkmaktadır. Yine bu kesme noktaları aralığında Güvenli İnternet anahtar kavramı son test sonuçlarında "Aile Profili” ve "Çocuk Profili" kelimeleri ile ifade edilmiştir. Öğrenciler ön test aşamasında bu anahtar kavrama çok farklı cevaplar verirken son test aşamasında Güvenli İnternet anahtar kavramını "Çocuk Profili” ve "Aile Profili”" ile ilişkilendirmeyi tercih etmişlerdir. Bu durum, öğrencilerin aldıkları "İnternet Kavramları Semineri” eğitimi sonrasında ön test aşamasında verdikleri cevaplara göre anahtar kavramlara ilişkin olarak son test aşamasında daha uygun cevaplar verdikleri sonucunu ortaya çıkarmaktadır.

Kesme noktas1 100-200 arası olan ön test sonucunda Arama Motoru anahtar kavramına arama motoru olmayan "Facebook" ve "YouTube" cevabı veren öğrenciler, son test sonucunda arama motoru olarak kullanılan "Yahoo" ve "Bing" kelimeleri ile cevap vermelerinin yanında yine bir arama motoru olmayan "Mozilla Firefox" kelimesi ile cevap vermişlerdir. Araştırma kapsamında öğrencilere verilen "İnternet Kavramları Semineri” eğitiminin öğrencilerin bilişsel durumlarını kısmen olumlu olarak etkilediği ve günlük hayatta kullanılan arama motoru sitelerini cevaplarına yansıttıkları görülmektedir. Yine bu kesme noktaları arasında Online Alışveriş anahtar kavramında ön test ve son test sonuçları benzerlikler göstermektedir. Her iki testte de "Gittigidiyor" ve "Markafoni” cevapları ortak olarak verilmiştir. Son test sonuçlarında "Morhipo" cevabı da bu siteler arasında yer almıştır. Buna göre öğrencilerin online alışveriş konusunda benzer fikirlere sahip olduğu ve benzer cevaplar verdikleri ortaya söylenebilir. Bu kesme noktaları arasında Sosyal Ağlar anahtar kavramına ise hem ön testte hem de son testte öğrenciler tarafından "Ask.fm” cevabı verilmiştir. Buna göre öğrencilerin bu siteyi günlük yaşamlarında yoğun olarak kullandıkları ve genel olarak kullandıklarının söylemek mümkündür.

Kesme noktası 50-100'e göre oluşturulmuş ön ve son kavram ağı haritalarında öğrencilerin kavram anahtarlara verdikleri cevap kelimeler açısından farklılıkların olduğu söylenebilir. Bu kesme noktasında öğrencilerin hem ön testte hem de son testte anahtar kavramların tamamına yakını ile ilgili cevaplar verdikleri ve fikirlerini belirttikleri görülmektedir. Ön kavram ağı haritasına göre, kesme noktası 50-100 arasında ön testte verilen cevaplarda öğrenciler sadece Lisanslı Yazılım anahtar kavramına cevap vermemişken, son testte göre oluşturulan son kavram ağı haritasında ise tüm anahtar kavramlara ilişkin cevap kelimeler ile yanıtlar vermiştir.

Kesme noktası 50-100'e göre oluşturulmuş ön kavram ağı haritasında öğrencilerin Web Tarayıc1 anahtar kavramına "Chrome" ve "İnternet” cevaplarını verdikleri görülmüştür. Ön test sonrasında anahtar kavramlara ilişkin olarak verilen "İnternet Kavramları Semineri” eğitimi sayesinde öğrencilerin son testte Web Tarayıı anahtar kavramına "İnternet”, "Safari” ve "Yahoo" cevap kelimeleri ile yanıtlar verdiği görülmektedir. Bu sonuca göre öğrencilerin "İnternet Kavramları Semineri” eğitimi sonrasında algılarında farklılıklar olduğu ve web tarayıcı olarak uygun ifadelerle cevap verdikleri görülmektedir. Burada öğrencilerin kendi kullandıkları web tarayıcı sitelerini cevaplarına yansıttıkları söylenebilir.

Kesme noktası 50-100'e göre oluşturulmuş ön kavram ağı haritasında öğrenciler tarafindan Online Oyun anahtar kavramına "Counter Strike”, "Wolfteam” ve "Knightonline” cevapları verilmiştir. Öğrencilerin son testte Online Oyun kavramına ilişkin olarak cevaplarının çeşitlendiği görülmektedir. "Counter Strike” cevap kelimesini kullanan öğrenci sayısında son testte bir artışın olduğu ve 100-200 kesme noktaları arasındaki sayıya (140) ulaşıldığı görülmektedir. Bu kesme noktasında ön testteki "Wolfteam" ve "Knightonline" cevap kelimelerine "Okey" cevap kelimesinin eklendiği görülmektedir. Sonuç olarak öğrencilerin genel olarak 
benzer oyunları oynadıkları ve cevaplarında da bunları kullandıklarını söylemek doğru bir çıkarım olacaktır.

Kesme noktası 50-100'e göre oluşturulmuş ön kavram ağı haritasında öğrenciler Köprü/Bağlantı (Link) anahtar kavramına "Boğaziçi Köprüsü” ve "İnternet” cevaplarını vermiştir. Bu kesme noktaları arasında ön testte öğrencilerin verdikleri cevapların bu anahtar kavramı tam olarak ifade etmediği görülmektedir. "İnternet Kavramları Semineri" eğitimi sonrasında son testte ise öğrenciler Köprü/Bağlantı anahtar kavramına "Facebook", "Bağlantı”, "Http”, “Adres”, "Müzik” ve "Video” cevapları ile yanıt vermişlerdir. Öğrencilerin son testte bu anahtar kavramla ile ilgili daha uygun cevaplar verdikleri ve algılarında olumlu yönde değişiklikler olduğu söylenebilir. Benzer şekilde öğrencilerin bu kesme noktasındaki ön testte İnternet Etiği anahtar kavramına "Bilmiyorum" cevabı ile bu anahtar kavramla ilgili fikirlerinin olmadığını açıkça ifade ettikleri görülmektedir. Öğrencilerin son testte İnternet Etiği anahtar kavramı ile ilgili "Saygı" ve "Ahlak" cevap kelimeleri ile cevaplar verdikleri görülmektedir. Öğrencilere ön test sonrasında verilen "İnternet Kavramları Semineri” eğitiminin etkili olduğu ve internet etiği konusunda öğrencilerin bu anahtar kavrama daha uygun cevap verdikleri sonucu ortaya çıkmaktadır. Yani eğitim semineri sonucunda öğrencilerin İnternet Etiği kavramını doğru algıladıklarını gösteren cevaplar verdikleri söylenebilir.

Kesme noktası 50-100'e göre oluşturulmuş ön kavram ağı haritasında Siber Zorbalık anahtar kavramına öğrenciler tarafından "Hacker” cevap kelimesi ile karşılık verildiği görülmektedir. Son kavram ağı haritasında öğrencilerin Siber Zorbalık anahtar kavramına "Şifre Kırma" ve "Hırsızlık" cevaplarını verdikleri görülmektedir. Ön test sonrasında öğrencilere verilen "İnternet Kavramları Semineri" eğitimi sayesinde ögrencilerin bu anahtar kavram ile ilgili bilgi düzeylerinin arttığı, "Hacker" kelimesini cevap kelime olarak tercih eden öğrenci sayısında artış olduğu ve bu kelimenin cevap frekansının 100-200 kesme noktası aralığına çıktığı söylenebilir. Bunun yanı sıra öğrencilerin 50-100 kesme noktası aralığına göre oluşturulan son kavram ağı haritasında Siber Zorbalık kavramını "Şifre Kırmak" ve "Hırsızlık" kelimeleri ile ilişkilendirdiği görülmektedir. Bu durum öğrencilerin aldıkları seminer eğitimi sayesinde bu anahtar kavrama daha uygun cevaplar verdikleri sonucunu ortaya çıkarmaktadır.

Kesme noktası 50-100'e göre oluşturulmuş ön kavram ağı haritasında öğrencilerin Online Eğitim anahtar kavramına "Ekol Hoca" ve "E-okul" cevap kelimeleri ile yanıtlar verdiği görülmektedir. Ön test sonrasında öğrencilere verilen "İnternet Kavramları Semineri” eğitimi sayesinde öğrencilerin bu anahtar kavram ile ilgili bilgi düzeylerinin arttığı, "Ekol Hoca" kelimesini cevap kelime olarak tercih eden öğrenci sayısında artış olduğu ve bu kelimenin cevap frekansının 100-200 kesme noktası aralığına çıktığı söylenebilir. Bunun yanı sıra öğrencilerin 50-100 kesme noktası aralığına göre oluşturulan son kavram ağı haritasında Online Eğitim kavramını "E-okul" cevap kelimesi ile ilişkilendirdiği görülmektedir. Bu anahtar kavrama verilen cevap kelimeye göre öğrencilerin genel olarak benzer siteler üzerinden ders çalışma ve araştırma yaptıklarını ifade etmek mümkün olacaktır.

Kesme noktası 50-100'e göre oluşturulmuş ön kavram ağı haritasında Upload-Download anahtar kavramına öğrenciler tarafından "Yüklemek" ve "Video" cevap kelimeleri ile karşılık verildiği görülmektedir. Son kavram ağı haritasında öğrencilerin Upload-Download anahtar kavramı için "İndirme", "Program" ve "Resim" cevap kelimelerini tercih ettikleri görülmektedir. Öğrenciler hem ön testte hem de "İnternet Kavramları Semineri" eğitimi sonrasında uygulanan son testte bu kesme noktasında farklı yanıtlar vermişlerdir. Bu durum öğrencilerin günlük yaşamlarında upload ve download işlemlerini farklı olarak düşünerek gerçekleştirdikleri sonucunu ortaya çıkarmaktadır.

Kesme noktası 50-100'e göre oluşturulmuş ön kavram ağı haritasında öğrencilerin Güvenli İnternet anahtar kavramına "TTnet" cevap kelimesi ile son kavram ağı haritasında ise "Aile Koruması" cevap kelimesi ile yanıt verdiği görülmektedir. Bu anahtar kavram için öğrencilerin her iki testte de farklı algıları ortaya çıkmıştır. Ancak ön test sonrası öğrencilere verilen “İnternet Kavramları Semineri” eğitimi öğrenci algılarında Güvenli İnternet kavramını bir servis sağlayıcı isminden öte Güvenli İnternet kavramına doğru yönelttiği görülmektedir. Seminer eğitimi sonrasında bu kavram ile ilgili bilgi düzeyinde artış olan öğrenciler bu kesme 
noktasında internet servis sağlayıcıların "aile koruması" sistemi ile Güvenli İnternet kavramını ilişkilendirmişlerdir.

Kesme noktası 50-100'e göre oluşturulmuş ön kavram ağı haritasında Arama Motoru anahtar kavramına öğrenciler tarafindan "İnternet" cevap kelimesi ile karşılık verildiği görülmektedir. Son kavram ağı haritasında öğrencilerin Arama Motoru anahtar kavramı için "Chrome", "Opera", "Bilgi” ve "İnternet" cevap kelimelerini tercih ettikleri görülmektedir. Bu cevaplar, öğrencilerin ön testte verdikleri cevaplara göre farklılıklar olduğunu göstermektedir. Öğrencilerin kendilerine verilen “İnternet Kavramları Semineri” eğitimi ile bu anahtar kavram ile ilgili bilgi düzeylerinde olumlu değişimlerin oluştuğu sonucu ortaya çıkarmaktadır.

Kesme noktası 50-100'e göre oluşturulmuş ön kavram ağı haritasında öğrencilerin Online Alışveriş anahtar kavramına "Morhipo", "Sahibinden", "Trendyol" ve "Ayakkabı" cevap kelimeleri ile son kavram ağı haritasında ise "Trendyol”, "Sahibinden”, "Hepsiburada” ve Kredi Kartı” cevap kelimeleri ile yanıtlar verdiği görülmektedir. Bu sonuca göre öğrencilerin Online Alışveriş anahtar kelimesine ön teste benzer şekilde cevap kelimeler kullandıkları ve son testte ek olarak "Kredi Kartı” cevap kelimesi ile online alışverişte kredi kartının önemli olduğu vurgusunu da yapmışlardır.

Kesme noktası 50-100'e göre oluşturulmuş ön kavram ağı haritasında Sosyal Ağlar anahtar kavramına öğrenciler tarafından "YouTube" ve "Messenger" cevap kelimeleri ile karşıllk verildiği görülmektedir. Son kavram ağı haritasında öğrencilerin Sosyal Ağlar anahtar kavramı için "Instagram” ve "YouTube” cevap kelimelerini tercih ettikleri görülmektedir. Buna göre öğrencilerin genel olarak eğitim semineri öncesinde de Sosyal Ağlar kavramı ile ilgili doğru algılara sahip oldukları söylenebilir.

Kesme noktası 50-100'e göre oluşturulmuş ön kavram ağı haritasında bulmayan Lisanslı Yazılım anahtar kavramı öğrencilere verilen "İnternet Kavramları Semineri” eğitimi sonrasında öğrenciler tarafından son testte "Windows", "Güvenilir" ve "İzin” cevap kelimeleri ile yanıtlanarak son kavram ağı haritasında yer almıştır. Bu durum, öğrencilerin lisanslı yazılımlar hakkında yeterli bilgilerinin olmadığını ancak anahtar kavramlarla ilgili verilen seminer eğitimi sayesinde bilgi düzeylerinde artış olduğu ve bu anahtar kavrama uygun cevaplar kelimeler kullandıklarını ortaya koymaktadır.

\section{Öneriler}

Tüm araştırmalarda olduğu gibi, bu araştırmada da bulgular 1şığında genelleme yapmayı engelleyecek bazı sınırlılıkları mevcuttur. Öncelikle, bu çalışma coğrafi olarak Türkiye'nin Konya ili ile sınırlıdır. Bu çalışmanın ve gelecekteki çalışmaların sonuçlarını daha genellenebilir yapmak için başka coğrafi bölgeler çalışmaya dahil edilebilir. İkinci olarak bu çalışmanın verileri bireylerin anahtar kavramlarla ilgili algılarını ortaya çıkarmak için kullanılan kelime ilişkilendirme testine dayalıdır. İleride yapılacak olan çalışmalar bireylerin algılarını ortaya çıkarmada başka teknikler (metafor, resim vb.) kullanabilir.

Kelime ilişkilendirme tekniği önceki araştırmalarda genellikle öğrencilerin bir kavram hakkındaki bilişsel yapılarını ortaya çıkarmak amacıyla kullanılagelmektedir. Bu araştırmada ise diğerlerinden farklı olarak öğrencilerin bilişsel yapılarıyla birlikte teknoloji alanındaki İnternet algılarını ortaya çıkarılmaya çalışılmıştır. Bundan sonra yapılacak araştırmalarda bu teknik kişilerin başka alanlardaki (Fen, matematik, sosyal vb.) kavramlar hakkında algı ve düşüncelerini ortaya çıkarmak amacıyla kullanılabilir.

$\mathrm{Bu}$ araştırmada lise öğrencilerinin internet algıları kelime ilişkilendirme testi kullanılarak incelenmiştir. İleride yapılacak olan araştırmalarda ilkokul, ortaokul ve yükseköğretimde öğrenim gören öğrencilerin internet algıları kelime ilişkilendirme tekniğiyle araştırılabilir. Böylece internet ile ilgili algıların farklı yaş grupları için değişimi incelenebilir.

\section{KAYNAKÇA}

Akış, A., \& Kaya, B. (2018). Coğrafya 4. sınıf öğrencilerinin "kuraklık" kavramıyla ilgili bilişsel yapılarının belirlenmesi. International Journal of Geography and Geography Education, 38, 58-68.

Akkoyunlu, B. (2002). Öğretmenlerin internet kullanımı ve bu konudaki öğretmen görüşleri. Hacettepe 
Üniversitesi Ĕ̈itim Fakültesi Dergisi, 22, 1-8.

Akturk, A. O., \& Sahin, I. (2010). Analysis of community college students' educational Internet use and metacognitive learning strategies. Procedia-Social and Behavioral Sciences, 2(2), 5581-5585.

Aktürk, A. O., \& Çiçek, S. (2017). Variables that predict perceptions of parents about their own children's levels of Internet addiction. SDU International Journal of Educational Studies, 4(2), 155-165.

Aktürk, A. O., Çelik, İ., Şahin, İ., \& Deniz, M. E. (2014). Facebook bağlanma stratejileri ölçeğinin Türkçe uyarlama çalışması. Illköğretim Online, 13(1), 319-333.

Aktürk, A. O., Emlek, B., \& Çelik, İ. (2017). Üniversite öğrencilerinin Facebook bağlanma stratejilerinin ve yaşam doyumlarının incelenmesi. Mersin Üniversitesi Ĕ̈itim Fakültesi Dergisi, 13(2), 512-530.

Aladağ C., Tapur, T., \& Duran, Y. (2018). Coğrafya öğretmen adaylarının güneş enerjisi konusundaki algilarının belirlenmesi. Gelecek Vizyonlar Dergisi, 2(3), 17-27.

Altan, M. Z. (2007). İnternet ve eğitim. Erciyes Üniversitesi Sosyal Bilimler Enstitüsü Dergisi, 2, 569-577.

Ay, M. (2011). Conceptual frameworks of university students regarding accounting. African Journal of Business Management, 5(5), 1570-1577.

Bahar, M., \& Kılıç, F. (2001). Kelime iletişim testi yöntemi ile Atatürk ilkeleri arasındaki kavramsal bağların araştırılması. IX. Ĕgitim Bilimleri Kongresi Bildirileri Kitabı. Bolu: Abant İzzet Baysal Üniversitesi.

Bahar, M., \& Özatlı, N. S. (2003). Kelime iletişim testi yöntemi ile lise 1. Sınıf öğrencilerinin canlıların temel bileşenleri konusundaki bilişsel yapılarının araştırılması. Balıkesir Üniversitesi Fen Bilimleri Enstitüsü Dergisi, 5(2), 75-85.

Bahar, M., Johnstone, A. H., \& Sutcliffe, R. G. (1999). Investigation of students' cognitive structure in elementary genetics through word associationtests. Journal of Biological Education, 33(3), 134-141.

Binark, M., \& Bek, M. G. (2010). Eleştirel medya okuryazarlı̆̆ kuramsal yaklaşımlar ve uygulamalar. İstanbul: Kalkedon Yayınları.

Büyüköztürk, Ş., Çakmak Kılıç, E., Akgün Ö. E., Karadeniz, Ş., \& Demirel, F. (2011). Bilimsel araştırma yöntemleri. Ankara: Pegem Akademi Yayıncılık.

Cohen, L., Manion, L., \& Morrison, K. (2013). Research methods in education. London: Routledge.

Çalık, D., \& Çınar, Ö. P. (2009). Geçmişten günümüze bilgi yaklaşımları bilgi toplumu ve internet. XI. Akademik Bilişim Konferansı Bildirileri Kitabı (s. 77-85), Malatya: İnönü Üniversitesi.

Çardak, O. (2009). The determination of the knowledge level of science students on energy flow through a word association test. Energy Education Science and Technology Part B, 1(1), 139-155.

Çelen, F. K., \& Seferoğlu, S. S. (2017). İnternet ortamında öğrencilerin bilgi arama biçimleri: Stratejiler, tarzlar, tutumlar, gözlemler ve sorunlarla ilgili bir değerlendirme. Ö. Demirel ve S. Dinçer (Ed.) içinde Eğitim bilimlerinde yenilik ve nitelik arayışı (2. Baskı) (s. 1147-1160). Ankara: Pegem Akademi Yayıncilik.

Çelen, F. K., Çelik, A., \& Seferoğlu, S. S. (2011). Çocukların internet kullanımları ve onları bekleyen çevrimiçi riskler. XIII Akademik Bilişim Konferansı Bildirileri Kitabı. Malatya: İnönü Üniversitesi.

Demirel, M., Yörük, M., \& Özkan, O. (2013). Çocuklar için güvenli internet: Güvenli internet hizmeti ve ebeveyn görüşleri üzerine bir araştırma. Mehmet Akif Ersoy Üniversitesi Sosyal Bilimler Enstitüsü Dergisi, 4(7), 54-68.

Eftekin, P. (2015). Ergenlik dönemindeki öğrencilerin internet bağımlılı̆̆ 1 ve anne baba tutumları arasındaki ilişkinin incelenmesi [Yayımlanmamış Yüksek Lisans Tezi]. Kayseri: Erciyes Üniversitesi.

Ekici, G., \& Kurt, H. (2014). Öğretmen adaylarının “Aids” kavramı konusundaki bilişsel yapıları: Bağımsız kelime ilişkilendirme testi örneği. Türkiye Sosyal Araştırmalar Dergisi, 183, 267-306.

Ekici, S., \& Uçak, N.Ö. (2012). İlköğretim öğrencilerinin İnternet’te bilgi arama davranışları. Türk Kütüphaneciliği, 26(1), 78-96.

Ercan, F., Taşdere, A., \& Ercan, N. (2010). Kelime ilişkilendirme testi aracılığıyla bilişsel yapının ve kavramsal değişimin gözlenmesi. Türk Fen Ĕ̆itimi Dergisi, 7(2), 136-154.

Eren, F. (2012). Illköğretim öğrencilerinin bilişim teknolojileri algllarının kelime ilişsilendirme testi kullanılarak incelenmesi (Yüksek Lisans Tezi). Konya: Necmettin Erbakan Üniversitesi, Eğitim Bilimleri Enstitüsü

Eren, F., Sahin, I., Celik, I., \& Akturk, A. O. (2014). Analysis of secondary school students' perceptions about information technologies through a word association test. Online Submission, 8(8), 2512-2515.

Ersoy, A., \& Türkkan, B. (2009). İlköğretim öğrencilerinin resimlerinde internet algısı. Elementary Education Online, 8(1), 57-73. 
Güneş, H., \& Gözüm, A.İ.C. (2013). İlköğretimde işlenen ekoloji konusunun 10. sınıf öğrencilerin ekosistem ekolojisi konusundaki hazırbulunuşluk düzeyleri üzerindeki etkisinin saptanmasında kelime ilişkilendirmenin etkisi. Ĕ̈itim ve Öğretim Araştırmaları Dergisi, 2(3), 240-256.

Güzel, M. (2006). Küreselleşme, internet ve gençlik kültürü. Küresel İletişim Dergisi, 1(1), 1-16.

Işıklı, M., Taşdere, M., \& Göz, N. L. (2011). Kelime ilişkilendirme testi aracılığıyla öğretmen adaylarının Atatürk ilkelerine yönelik bilişsel yapılarının incelenmesi. Uşak Üniversitesi Sosyal Bilimler Dergisi, 4(1), 50-72.

Karal, H., \& Şimşek, A. (2006). Okulların internete taşınmasında BÖTEB'lerin (Bilgisayar ve Öğretim Teknolojileri Eğitimi Bölümü) rolü. XI. Türkiye’de Internet Konferansı Bildirileri Kitabı (s. 221225). Ankara: TOBB Ekonomi ve Teknoloji Üniversitesi.

Kızılay, E. (2018). Fen bilgisi öğretmen adaylarının mühendislik kavramına ilişkin bilişsel yapılarının incelenmesi. Journal of Social and Humanities Sciences Research (JSHSR), 5(27), 2932-2938.

Koç, B., \& Tatlı, H. (2017). Üniversite öğrencilerinin sosyal ağ sitelerine yönelik tutum ve davranışları. Bingöl Üniversitesi Sosyal Bilimler Enstitüsü Dergisi, 7(13), 71-82.

Kurtaslan, Z., Aydın, B., \& Özer, B. (2018). Kelime ilişkilendirme testi aracılığıyla ortaokul ve lise öğrencilerinin "müzik öğretmeni” kavramına yönelik bilişsel yapılarının belirlenmesi. Ekev Akademi Dergisi, 22(74), 377-392.

Kurulgan, M., \& Argan, M. (2007). Anadolu üniversitesi öğrencilerinin internet üzerinden bilgi arama davranıșları. Atatürk Üniversitesi Sosyal Bilimler Enstitüsü Dergisi, 9(1), 291-304.

Kuzu, A. (2011). İnternet ve aile. Aile ve Toplum Dergisi, 7(27), 9-31.

Özatlı, N. S., \& Bahar, M. (2010). Öğrencilerin boşaltım sistemi konusundaki bilişsel yapılarının yeni teknikler ile ortaya konması. Abant İzzet Baysal Üniversitesi Dergisi, 10(2), 9-26.

Özatlı, N. S., \& Bahar, M. (2010). Öğrencilerin boşaltım sistemi konusundaki bilişsel yapılarının yeni teknikler ile ortaya konması. Abant İzzet Baysal Üniversitesi Dergisi, 10(2), 9-26.

Özbay, A., \& Yetişener, F. (2000). Internet programları rehberi. İstanbul: Hayat Yayıncılık.

Özen, Y., Gülaçtı, F., \& Çıkılı, Y. (2004). Eğitim bilimleri ve internet. Doğu Anadolu Bölgesi Araştırmaları, $1,52-58$.

Senyuva, E. \& Kaya, H. (2013). Metaphors for the internet used by nursing students in Turkey: A qualitative research. Egitim Arastirmalari-Eurasian Journal of Educational Research, 50, 87-106.

Shavelson, R. J. (1974). Methods for examining representations of a subject-matter structure in a student's memory. Journal of Research in Science Teaching, 11(3), 231-249.

Silkü, H. A. (2009). İletişim fakültesi öğrencilerinin internetten alışverişe yönelik tutumları. Journal of Yasar University, 4(15), 2281-2301.

Şahin, Ş., \& Baturay, M. H. (2013). Ortaöğretim öğrencilerinin internet kavramına ilişkin algılarının değerlendirilmesi: Bir metafor analizi çalışması. Kastamonu Eğitim Dergisi, 21(1), 177-192.

Tercan, İ., Sakarya S., \& Çoklar, A. N. (2012). Çocukların gözüyle onların internet kullanım profilleri ve ailelerin getirdiği sınırlamalar: Anamur ilçe örneği. E-Journal of New World Sciences Academy, 7(1),1306-1311.

Weiser, E. B. (2001). The functions of Internet use and their social and psychological consequences. CyperPschology \& Behavior, 4(6), 723-743.

Yalvaç, H. G. (2008). İşbirlikçi ögrrenme yaklaşımının öğretmen adaylarının çevreye ilişkin zihinsel yapılarına etkisi (Yüksek Lisans Tezi). Bolu: Abant İzzet Baysal Üniversitesi.

Yıldırım, A., \& Şimşek, H. (2006). Sosyal bilimlerde nitel araştırma yöntemleri (5. Baskı). Ankara: Seçkin Yayıncilık.

Yıldız, C., \& Abdüsselam, M. S. (2016). Ortaokul ve ortaöğretim öğrencilerinin internet kullanımına yönelik yaşantıları. Ĕgitim ve Öğretim Araştırmaları Dergisi, 5(1), 263-276.

\section{EXTENDED ABSTRACT}

\section{Introduction:}

Today, the advantages of the internet, especially in storing, accessing and sharing information with others, are among the features that make it attractive. In order to improve the knowledge and skill levels of students living in today's world, which is described as the internet age, their perceptions of the internet should be revealed first. After determining the current situation, it would be more appropriate to train students in areas that need improvement. Due to the intense use of the Internet, it is important to determine the students' level of internet use knowledge and their attitudes towards the 
internet, in order to increase the efficiency and effectiveness of the internet use process in education.

\section{Materials and Methods:}

This study, which aims to determine the internet perceptions of high school students and to determine how the relationships between the concepts related to the internet are formed, was carried out according to the phenomenology design, one of the qualitative research designs. The word association test was used to collect the data of the study. The participants of the study consist of a total of 475 high school students, 251 female and 224 male, attending different departments of Anatolian Vocational High School of Commerce in Konya metropolitan city. The word association test, which is composed of 12 key concepts about the internet, was administered to the students as pre-test and post-test. At the stage of the administration of the word association test as a pre-test, the students were asked to write down the words about the keywords that first came to their minds. After the implementation of the word association test as a pre-test, the students were given "Internet Concepts Seminar" training. The same word association test was administered to the students as a post-test right after this seminar. A frequency table was created from the data obtained as a result of the administration of the word association test as a pre-test and post-test. With the help of this frequency table, the pre and post conceptual network maps were drawn revealing the students' cognitive concepts regarding the internet. The data were analyzed and interpreted according to the relationships that emerged in the pre and post concept networks.

\section{Findings:}

It is seen that in the number of the pre-answers given by the students to the key concepts, they gave answers mostly to the Search Engine (2.249) key concept and the least to the Web Browser (2.213) key concept. When the number of the post-answers of the students is examined, it is seen that they mostly gave answers about the Online Shopping (2.138) key concept and the least about the Internet Ethics (2.096) key concept. Considering the total number of answers given by the students to the key concepts, it was determined that they produced 26.733 words in the word association pre-test and 25.427 words in the word association post-test. When each key concept is examined one by one before and after the "Internet Concepts Seminar", it can be said that the students produced more response words in the word association pre-test than in the word association post-test. In the pre-test and post-test stages, the answers given by the students to the key concepts and the types of answers and the most frequently used answers for the key concepts were as follows: While 2213 answers were given by the students in the pre-test for the Web Browser key concept, 39 answer types were determined. In the post-test, while 2119 answers were given to this key concept, 29 answer types were determined. The most used word by the students for this key concept in the pretest was Yandex (197), while in the post-test it was Mozilla Firefox (252). While 2234 answers were given by the students in the pre-test for the Bridge/Link key concept, 66 answer types were determined. In the post-test, while 2115 answers were given to this key concept, 71 answer types were determined. While the most used word by the students in the pre-test for this key concept was Facebook (106), it was also Facebook (79) in the post-test. While 2130 answers were given by the students in the pre-test for the Search Engine key concept, 28 answer types were determined. In the post-test, while 2130 answers were given to this key concept, 28 answer types were determined. While the word most used by the students in the pre-test for this key concept was Google (361), it was also Google (373) in the post-test. While 2228 answers were given by the students in the pre-test for the Upload-Download key concept, 34 answer types were determined. In the post-test, while 2123 answers were given to this key concept, 51 answer types were determined. The most used word by the students for this key concept in the pre-test was Download (177), while in the post-test it was Music-mp3 (214). While 2221 answers were given by the students in the pre-test for the Online Education key concept, 57 answer types were determined. In the post-test, while 2105 answers were given to this key concept, 70 answer types were determined. While the word that the students used most in the pre-test for this key concept was Vitamin (137), it was also Vitamin (168) in the post-test. While 2233 answers were given by the students in the pre-test for the Online Shopping key concept, 44 answer types were determined. In the post-test, while 2138 answers were given to this key concept, 49 answer types were determined. While the word that the students used most in the pre-test for this key concept was Gittigidiyor (155), it was also Gittigidiyor (158) in the post-test. While 2233 answers were given by the students in the pre-test for the Social Networks key concept, 32 answer types were determined. In the post-test, 2121 answers were given to this key concept, while 30 answer types were determined. While the word that the students used most in the pre-test for this 
key concept was Facebook (392), it was also Facebook (407) in the post-test. While 2240 answers were given by the students in the pre-test for the Online Game key concept, 48 answer types were determined. In the post-test, while 2132 answers were given to this key concept, 64 answer types were determined. While the word that the students used most in the pre-test for this key concept was Metin 2 (189), it was also Metin 2 (296) in the post-test. While 2220 answers were given by the students in the pre-test for the Secure Internet key concept, 16 answer types were determined. In the post-test, while 2117 answers were given to this key concept, 53 answer types were determined. The most used word by the students for this key concept in the pre-test was TTnet (85), while in the post-test it was Child Profile (134). While 2223 answers were given by the students in the pre-test for the cyberbullying key concept, 61 answer types were determined. In the post-test, while 2113 answers were given to this key concept, 60 answer types were determined. While the word that the students used most in the pre-test for this key concept was Hacker (60), while it was also Hacker (114) in the post-test. While 2215 answers were given by the students in the pre-test for the Internet Ethics key concept, 49 answer types were determined. In the posttest, while 2096 answers were given to this key concept, 71 answer types were determined. The most used word by the students for this key concept in the pre-test was I don't know (71), while in the post-test it was the Rules (103). While 2224 answers were given by the students in the pre-test for the Licensed Software key concept, 68 answer types were determined. In the post-test, while 2118 answers were given to this key concept, 68 answer types were determined. While the word that the students used most in the pre-test for this key concept was Windows (102), it was also Windows (80) in the post-test.

\section{Discussion:}

When we analyzed the word association pre-test and post-test results in terms of the number of words produced by the students, we concluded that they produced more words in the word association pre-test than the post-test. This can be explained by the fact that after the students took the "Internet Concept Seminar", they eliminated the wrong words in their cognitive structures about the concepts presented to them and did not repeat them in the word association post-test. However, the high number of words produced by students may not provide much information about the quality of the knowledge about the concept. The important thing in the word association test is the property and quality of the words. The property and quality of the words depends on their being meaningful, scientific, accurate and directly related to the concept. It has also been stated by many researchers (Bahar et al., 1999; Shavelson, 1974; Yalvaç, 2008) that the number and variety of answer words cannot explain understanding the concept alone, and that the quality of the answer words is also important.

\section{Conclusion and Suggestions:}

As in other studies, this study has some limitations that prevent generalization in the light of the findings. First, this study is geographically limited to the province of Konya in Turkey. Other geographic regions may be included in the study to make the results of this study and future studies more generalizable. Second, the data of this study is based on the word association test used to reveal individuals' perceptions of key concepts. Future studies may use other techniques (metaphor, painting, etc.) to reveal the perceptions of individuals.

The word association technique has been used in previous studies to reveal students' cognitive structures about a concept. In this study, unlike the others, it was tried to reveal the students' cognitive structures and their perceptions of the Internet in the field of technology. In future research, this technique can be used to reveal individuals' perceptions and conceptions about concepts in other fields (science, mathematics, social, etc.).

In this study, internet perceptions of high school students were examined using the word association test. In future studies, the internet perceptions of students studying in primary, secondary and higher education can be investigated by word association technique. Thus, the change in perceptions about the internet for different age groups can be examined. 